\title{
Advances in the Application of Nanocatalysts in Photocatalytic Processes for the Treatment of Food Dyes: A Review
}

\author{
Jennifer María Navia-Mendoza ${ }^{1}{ }^{(\mathbb{D}}$, Otoniel Anacleto Estrela Filho ${ }^{2}$, Luis Angel Zambrano-Intriago ${ }^{3}{ }^{(\mathbb{B}}$, \\ Naga Raju Maddela ${ }^{4}\left(\mathbb{D}\right.$, Marta Maria Menezes Bezerra Duarte ${ }^{5}$, Luis Santiago Quiroz-Fernández ${ }^{6}$, \\ Ricardo José Baquerizo-Crespo ${ }^{1}(\mathbb{D})$ and Joan Manuel Rodríguez-Díaz ${ }^{1,2,3, * \mathbb{(}}$
}

Citation: Navia-Mendoza, J.M.; Filho, O.A.E.; Zambrano-Intriago, L.A.; Maddela, N.R.; Duarte, M.M.M.B.; Quiroz-Fernández, L.S.; Baquerizo-Crespo, R.J.;

Rodríguez-Díaz, J.M. Advances in the Application of Nanocatalysts in Photocatalytic Processes for the Treatment of Food Dyes: A Review. Sustainability 2021, 13, 11676. https:// doi.org/10.3390/su132111676

Academic Editor: Antonio Zuorro

Received: 23 August 2021

Accepted: 30 September 2021

Published: 22 October 2021

Publisher's Note: MDPI stays neutral with regard to jurisdictional claims in published maps and institutional affiliations.

Copyright: (c) 2021 by the authors. Licensee MDPI, Basel, Switzerland. This article is an open access article distributed under the terms and conditions of the Creative Commons Attribution (CC BY) license (https:// creativecommons.org/licenses/by/ $4.0 /)$.
1 Departamento de Procesos Químicos, Facultad de Ciencias Matemáticas, Físicas y Químicas, Universidad Técnica de Manabí, S/N, Avenida Urbina y Che Guevara, Portoviejo 130104, Ecuador; jnavia2880@utm.edu.ec (J.M.N.-M.); ricardo.baquerizo@utm.edu.ec (R.J.B.-C.)

2 Programa de Pós-Graduação em Engenharia Química, Universidade Federal da Paraíba, Cidade Universitária, João Pessoa 58051-900, Brazil; otoniel.filho@academico.ufpb.br

3 Laboratorio de Análisis Químicos y Biotecnológicos, Instituto de Investigación, Universidad Técnica de Manabí, S/N, Avenida Urbina y Che Guevara, Portoviejo 130104, Ecuador; angel.zambrano@utm.edu.ec

4 Departamento de Ciencias Biológicas, Facultad de Ciencias de la Salud, Universidad Técnica de Manabí, S/N, Avenida Urbina y Che Guevara, Portoviejo 130104, Ecuador; mnraju8875@gmail.com

5 Departamento de Engenharia Química, Universidade Federal de Pernambuco, Av. Prof. Arthur de Sá, S/N, Recife 50740-521, Brazil; marta.duarte@ufpe.br

6 Instituto de Posgrado, Universidad Técnica de Manabí, S/N, Avenida Urbina y Che Guevara, Portoviejo 130104, Ecuador; santiago.quiroz@utm.edu.ec

* Correspondence: joan.rodriguez@utm.edu.ec

\begin{abstract}
The use of food additives (such as dyes, which improve the appearance of the products) has become more prominent, due to the rapid population growth and the increase in demand for beverages and processed foods. The dyes are usually found in effluents that are discharged into the environment without previous treatment; this promotes mass contamination and alters the aquatic environment. In recent years, advanced oxidation processes (AOPs) have proven to be effective technologies used for wastewater treatment through the destruction of the total organic content of toxic contaminants, including food dyes. Studies have shown that the introduction of catalysts in AOPs improve treatment efficiency (i.e., complete decomposition without secondary contamination). The present review offers a quick reference for researchers, regarding the treatment of wastewater containing food dyes and the different types of AOPs, with different catalyst and nanocatalyst materials obtained from traditional and green chemical syntheses.
\end{abstract}

Keywords: advanced oxidation processes; food dyes; nanomaterials; nanocatalyst; green nanocatalyst

\section{Introduction}

Food dyes are used worldwide and are classified as natural, semi-synthetic, and synthetic [1]. Owing to their stability, performance, and low cost-synthetic and semi-synthetic dyes are increasingly being used in the food industry [2]. However, these compounds are not eco-friendly as they are resistant to biological oxidation (complex molecular structure) and are, therefore, environmental concerns [3]. There are more than 100,000 commercial dyes available, of which approximately $10-15 \%$ of the dyes usually enter the environment through industrial effluents without prior treatment [4]. When these effluents are mixed with clean water they can unbalance the recommended level of organic and inorganic parameters in water bodies [5], impeding the processes of self-purification and biological degradation due to limited light transmittance [6]. Moreover, due to their recalcitrant nature, xenobiotic, highly toxic, and carcinogenic properties, they end up affecting the health of people and ecosystems in general [1,2,7-10]. 
AOPs are being studied to reduce the presence of dyes in wastewater, to promote the degradation of the pollutant until its mineralization, and finally, to obtain a regenerated effluent [11]. Within the AOPs, homogeneous processes are researched, which are widely used in the elimination of dyes. However, their reactions take place in the same phase, making it difficult to separate them from the reaction medium, in addition to presenting drawbacks, such as high operational costs and energy requirements, acidification of the effluent (Fenton process), and the need to combine with other oxidative processes to improve their degradation yield. Alternatives to improve the degradation performance have been proposed, and, in turn, the operating conditions of the process, such as the use of heterogeneous processes with the application of catalysts (e.g., metal oxides, titanium dioxide, etc.); however, there is a risk of contamination due to the precipitation of toxic metals during the treatment. Therefore, to counteract these potential problems, the use of catalysts (in nanometer sizes) has emerged as a viable alternative due to their unique properties (e.g., large surface area and low concentration) [12].

Nanomaterials are attracting attention due to the degradation of toxic organic pollutants. Unlike conventional catalysts, nanocatalysts can achieve complete mineralization of contaminants in an advanced oxidation process, owing to their chemical reactivities, catalytic activities, electron flow, and other complementary properties, such as physicochemical and thermal stability and large surface areas [13-15]. In addition, they decrease operating costs since they can be reused during several reaction cycles [16]. This paper aims to perform a literature review on the degradation of food dyes by applying AOPs, focusing on catalysts and nanocatalysts.

\section{Dyes in the Food Industry}

Dyes are complex unsaturated aromatic compounds that exhibit good color, intensity, and solubility [17]. For their part, food dyes differ in origin (vegetable, mineral, or insect sources, to those chemically synthesized [18]), and have been established as necessary for the processing of various foods. Scotter [19] classified food dyes into six groups according to their chemical structures: Azo (monoazo, diazo, and triazo), triarylmethane, azopyrazolone, xanthene, quinoline, and indigoid. Out of the above, only $45-47 \%$ are biodegradable $[17,20]$. Table 1 presents a series of synthetic dyes, grouped according to Scotter [19] and approved by the European Union (E Number) and the United States of America. Dyes that have the greatest applications in the food industry, as well as the adverse effects they could cause if surpassing the average daily intake (ADI) limit specified by the European Food Safety Authority (EFSA), are listed as references. 
Table 1. Synthetic food dyes classification.

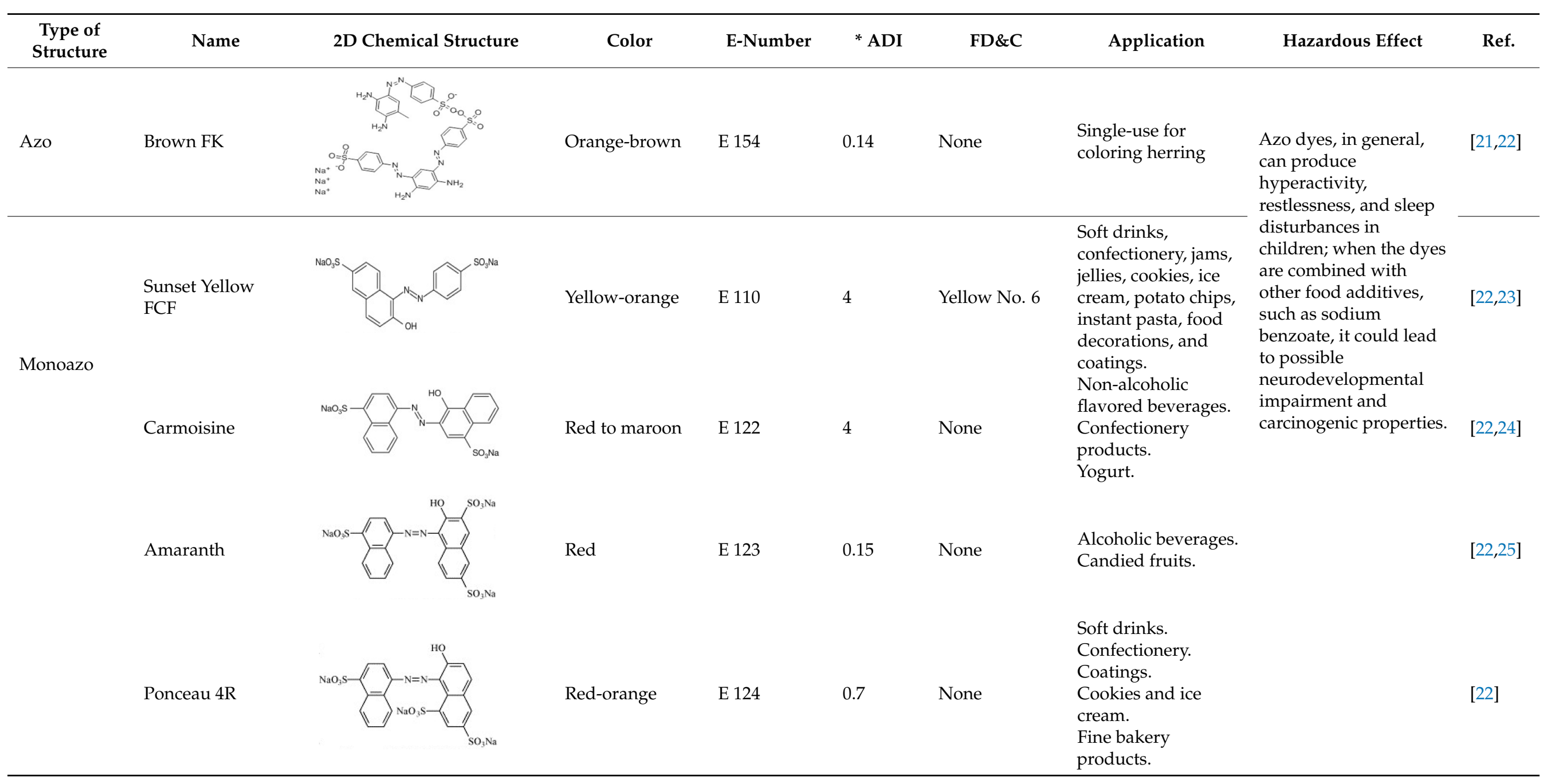


Table 1. Cont

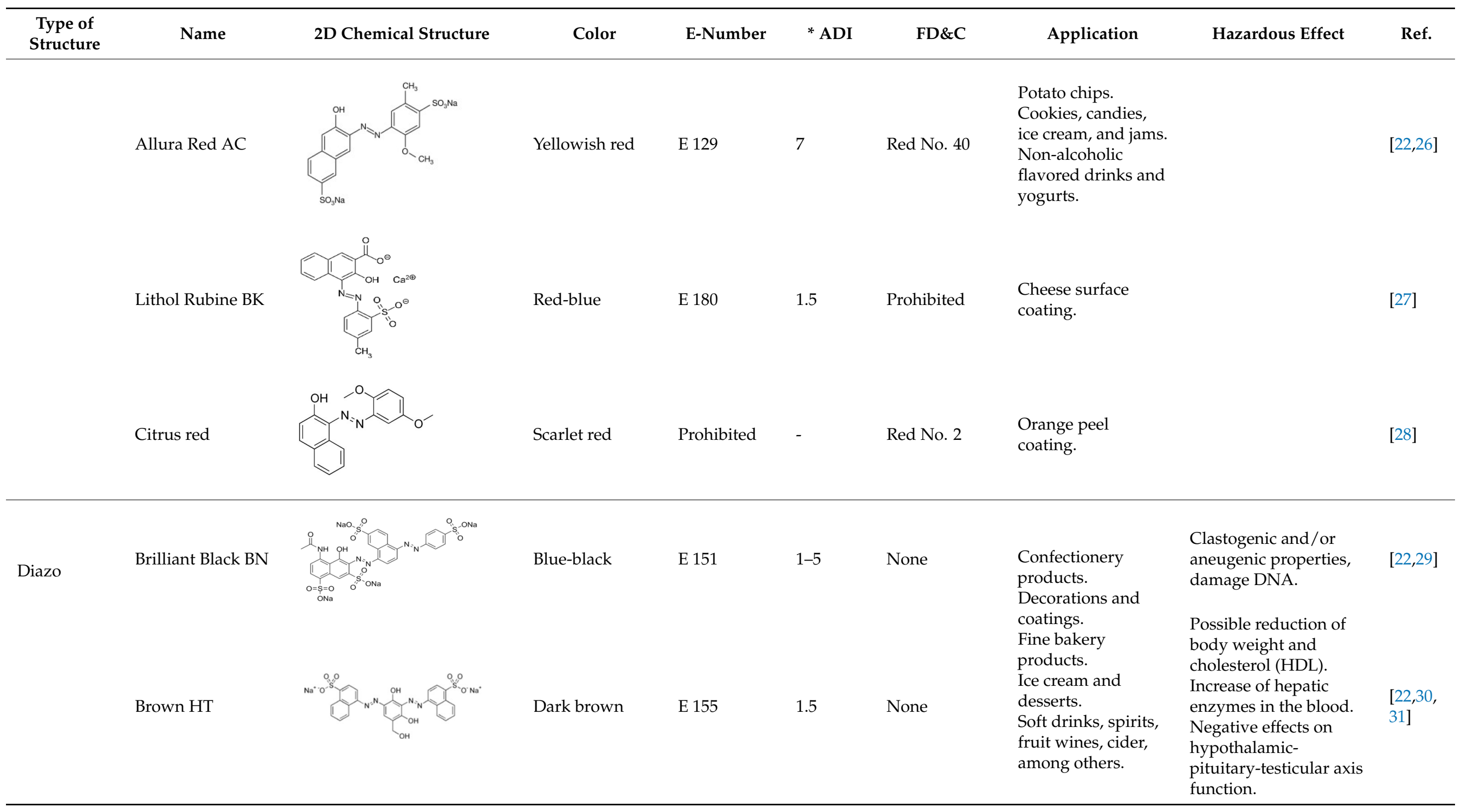


Table 1. Cont.

\begin{tabular}{|c|c|c|c|c|c|c|c|c|c|}
\hline $\begin{array}{c}\text { Type of } \\
\text { Structure }\end{array}$ & Name & 2D Chemical Structure & Color & E-Number & ${ }^{*} \mathrm{ADI}$ & FD\&C & Application & Hazardous Effect & Ref. \\
\hline \multirow[t]{4}{*}{ Triarylmethar } & Patent Blue V & $\left(\mathrm{H}_{5}\right)_{2}$ & Violet blue & E 131 & 5 & None & $\begin{array}{l}\text { Surface coating of } \\
\text { cheese and edible } \\
\text { casings. } \\
\text { Alcoholic beverages, } \\
\text { soft drinks, and } \\
\text { other food products. }\end{array}$ & $\begin{array}{l}\text { Anaphylactic reactions } \\
\text { Alterations of } \\
\text { hematological } \\
\text { parameters. }\end{array}$ & [32] \\
\hline & Brilliant Blue FCF & & Greenish blue & E 133 & 6 & Blue No.1 & $\begin{array}{l}\text { Dairy products. } \\
\text { Sweets. } \\
\text { Beverages. }\end{array}$ & Carcinogenic effect. & {$[33,34]$} \\
\hline & Green S & & Blue-green & E 142 & 5 & None & $\begin{array}{l}\text { Confectionery } \\
\text { products. } \\
\text { Decorations and } \\
\text { coatings. } \\
\text { Ice cream, desserts. } \\
\text { Processed peas. }\end{array}$ & $\begin{array}{l}\text { Mild anemia (transient), } \\
\text { increased cecal weight, } \\
\text { thyroid degeneration, } \\
\text { enlarged lymph nodes } \\
\text { in the intestinal wall. }\end{array}$ & [35] \\
\hline & Fast Green FCF & & Blue-green & Prohibited & - & Green No. 3 & $\begin{array}{l}\text { Peas. } \\
\text { Vegetables. } \\
\text { Fish. } \\
\text { Desserts, dry bakery } \\
\text { mixes, and sauces. }\end{array}$ & $\begin{array}{l}\text { Chromosomal } \\
\text { aberration } \\
\text { Inhibition of } \\
\text { neurotransmitter } \\
\text { release. }\end{array}$ & {$[34,36]$} \\
\hline \multicolumn{2}{|c|}{ Azopyrazolone Tartrazine } & & Yellow & E 102 & 7.5 & Yellow No.5 & $\begin{array}{l}\text { Desserts and sweets. } \\
\text { French fries. } \\
\text { Muesli, corn flakes, } \\
\text { noodles, tartar } \\
\text { sauce, mustard, and } \\
\text { bouillon cubes. } \\
\text { Energy drinks }\end{array}$ & $\begin{array}{l}\text { Migraine. } \\
\text { Asthma. } \\
\text { Skin conditions } \\
\text { (urticaria). }\end{array}$ & {$[22,36]$} \\
\hline
\end{tabular}


Table 1. Cont.

\begin{tabular}{|c|c|c|c|c|c|c|c|c|c|}
\hline $\begin{array}{l}\text { Type of } \\
\text { Structure }\end{array}$ & Name & 2D Chemical Structure & Color & E-Number & ${ }^{*} \mathrm{ADI}$ & FD\&C & Application & Hazardous Effect & Ref. \\
\hline Xanthene & Erythrosine & & Blue pink & E 127 & 0.1 & Red No.3 & $\begin{array}{l}\text { Cocktails. } \\
\text { Candied cherries. }\end{array}$ & $\begin{array}{l}\text { Oncogenic effect on the } \\
\text { rat thyroid gland. }\end{array}$ & {$[28,37]$} \\
\hline Indigo & Indigo carmine & $\mathrm{H}$ & Deep blue & E 132 & 5 & Blue No. 2 & $\begin{array}{l}\text { Tablets and } \\
\text { capsules. } \\
\text { Coatings. } \\
\text { Ice cream, cookies, } \\
\text { candies. } \\
\text { Confectionery. }\end{array}$ & Asthma. & [39] \\
\hline
\end{tabular}

${ }^{*}$ ADI, average daily intake (mg/kg body weight/day); FD\&C, Federal Food, Drug, and Cosmetic Act. 
From the aforementioned groups of dyes, azo dyes (azo, monoazo, and diazo) are considered high pollutants, and they represent $70 \%$ of all dyes. In addition, their biological degradations are difficult, with consequent inhibition of microbial activity and cell death when found in high concentrations in the effluent [40]. These are toxic and refractory to conventional treatment processes due to their resistance to physicochemical destruction and they lack biodegradability [41].

In addition, certain parameters of the receiving medium are altered, such as the color, $\mathrm{pH}$, biochemical oxygen demand (BOD), chemical oxygen demand (COD), total organic carbon (TOC), and suspended solids, among others. On the other hand, the interruption of the photosynthetic process in marine plants causes eutrophication and, thus, the uncontrolled release of mineral elements, such as nitrates, nitrites, and phosphates [41]. Therefore, in the search for new alternatives for the degradation of this type of dye, Wang and $\mathrm{Xu}$ [42] proposed the combination of AOPs (as pretreatment) to be subsequently treated with conventional biological processes (aerobic process), being considered efficient for their degradation. This is how AOPs have been introduced in recent years for the remediation of problems related to the contamination of the aquatic environment by dyes, allowing the removal of a wide range of organic and inorganic pollutants from water and wastewater [43].

\section{Advanced Oxidation Process}

The AOP is one of the most widely used processes for water treatment involving the formation of radicals, e.g., highly reactive hydroxyl radicals $(\bullet \mathrm{OH})$, superoxide anion radical $\left(\mathrm{O}_{2}{ }^{-}\right)$, hydroperoxyl radical $\left(\mathrm{HO}_{2} \bullet\right)$ or alkoxyl radical $(\mathrm{RO} \bullet)$, with the $\mathrm{HO} \bullet$ radicals attracting the most attention in this area, as they allow the degradation of organic matter for its complete mineralization to $\mathrm{CO}_{2}$ and $\mathrm{H}_{2} \mathrm{O}[44,45]$.

Specifically, the hydroxyl radical $(\bullet \mathrm{OH})$ has an oxidation potential between $2.8 \mathrm{~V}$ $(\mathrm{pH} 0)$ and $1.95 \mathrm{~V}(\mathrm{pH} \mathrm{14})$ vs. saturated calomel electrode (SCE), the most commonly used reference electrode. Being non-selective, it reacts rapidly with various species of the order $10^{6}-10^{10} \mathrm{M}^{-1} \mathrm{~s}^{-1}$ [46-48]. The mechanism of $\bullet \mathrm{OH}$ radicals involves the reaction with organic contaminants via four basic pathways: (i) radical addition; (ii) hydrogen abstraction; (iii) electron transfer; and (iv) radical combination. In addition, carbon radicals (R.or R--OH) are generated and can be transformed into organic peroxyl radicals (ROO) with $\mathrm{O}_{2}[47,49]$. Additionally, there is the combination of a strong oxidizing agent, such as ozone $\left(\mathrm{O}_{3}\right)$, transition metal ion catalysts, or photocatalysts, such as $\mathrm{Fe}^{2+}$ or $\mathrm{TiO}_{2}$, the latter being the most commonly used [50]. AOPs were first suggested in 1980 for drinking water treatment. However, in later years, their applicability mostly focused on oxidative treatments to different wastewaters. Thus, it was considered a new alternative for the elimination of organic pollutants classified as bio-recalcitrant and for the inactivation of pathogenic microorganisms that were difficult to treat by conventional methods [51-55].

Table 2 shows the source of hydroxyl radicals of homogeneous and heterogeneous AOPs, each process has its advantages and disadvantages, providing a thorough evaluation to select the most efficient process for each dye to be treated.

Table 2. Source of hydroxyl radicals of AOPs.

\begin{tabular}{llll}
\hline \multicolumn{1}{c}{ AOP } & \multicolumn{1}{c}{ Source of Radicals OH } & \multicolumn{1}{c}{ Advantages } & \multicolumn{1}{c}{ Disadvantages } \\
\hline $\begin{array}{l}\text { Electrochemical } \\
\text { oxidation }\end{array}$ & $\begin{array}{l}\text { Electricity, 2-20 A } \\
\text { (water electrolysis) }\end{array}$ & $\begin{array}{l}\text { High-energy efficiency. } \\
\text { Operates at ambient conditions. }\end{array}$ & Selective \\
\hline $\begin{array}{l}\text { Sonochemical } \\
\text { oxidation }\end{array}$ & $\begin{array}{l}\text { Ultrasound } 20 \mathrm{kHz}-2 \mathrm{MHz} \\
\text { (water sonolysis) }\end{array}$ & $\begin{array}{l}\text { Does not require the addition of } \\
\text { chemicals or catalysts. } \\
\text { Operates at ambient conditions. }\end{array}$ & $\begin{array}{l}\text { It needs to be combined with other } \\
\text { oxidative processes to improve its } \\
\text { degradation performance. }\end{array}$ \\
\hline
\end{tabular}


Table 2. Cont.

\begin{tabular}{clll}
\hline AOP & Source of Radicals $\mathbf{O H}$ & \multicolumn{1}{c}{ Advantages } & \multicolumn{1}{c}{ Disadvantages } \\
\hline Sonoelectrchemistry & $\begin{array}{l}\text { Electricity, 2-20A } \\
\text { Ultrasound } 20 \mathrm{kHz}-2 \mathrm{MHz}\end{array}$ & $\begin{array}{l}\text { Fast reaction rate. } \\
\text { Guaranted degradation } \\
\text { efficiency. } \\
\text { Increased energy efficiency. }\end{array}$ & $\begin{array}{l}\text { Greater emphasis on the frequency and } \\
\text { acoustic power, electrode positioning, cell } \\
\text { geometry, and the distance between the } \\
\text { tip of the ultrasonic horn and the } \\
\text { electrode. }\end{array}$ \\
\hline
\end{tabular}

Increased color removal.

No sludge or hazardous by-products.

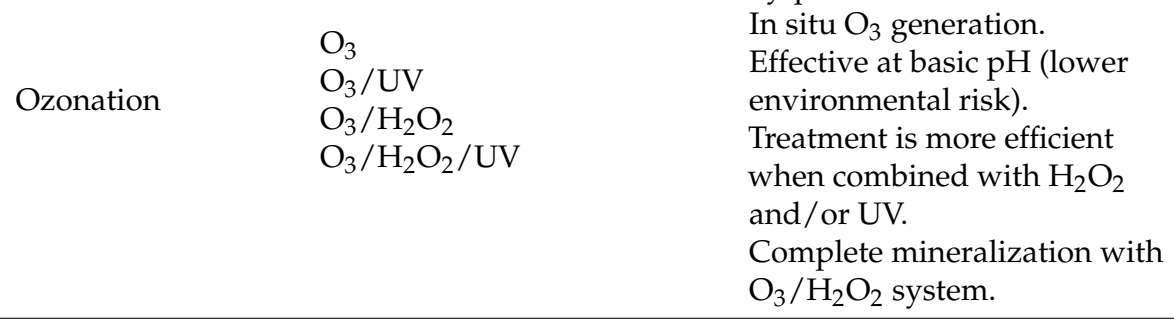

\begin{tabular}{|c|c|c|c|}
\hline \multirow{6}{*}{$\begin{array}{l}\text { Processes based on } \\
\mathrm{H}_{2} \mathrm{O}_{2}\end{array}$} & $\mathrm{H}_{2} \mathrm{O}_{2} / \mathrm{UV}$ & $\begin{array}{l}\text { The formation of bromate } \\
\text { is suppressed. }\end{array}$ & Lower mineralization rate. \\
\hline & $\mathrm{H}_{2} \mathrm{O}_{2} / \mathrm{Fe}^{2+}$ (Fenton) & $\begin{array}{l}\text { Lower energy consumption } \\
\text { than ozone. } \\
\text { Does not form bromates. }\end{array}$ & $\begin{array}{l}\text { Expensive. } \\
\text { The strict control of } \mathrm{H}_{2} \mathrm{O}_{2} / \mathrm{Fe}^{2+} \text { ratio. } \\
\text { Continuous addition of ferrous ions (high } \\
\text { sludge deposition). } \\
\text { An acidic medium is required for } \mathrm{OH} \\
\text { radical generation. } \\
\mathrm{pH} 3 \text { is the optimum operating } \mathrm{pH} \\
\left(\mathrm{Fe}(\mathrm{OH})_{3} \text { precipitation at } \mathrm{pH}>4 \text {. }\right.\end{array}$ \\
\hline & $\begin{array}{l}\mathrm{H}_{2} \mathrm{O}_{2} / \mathrm{Fe}^{3+} \text { (Fenton-like) } \\
\mathrm{H}_{2} \mathrm{O}_{2} / \mathrm{Fe}^{3+} / \mathrm{UV} \\
\text { (photo-Fenton-like) }\end{array}$ & $\begin{array}{l}\text { Using } \mathrm{Fe}^{3+} \text { ion is less expensive } \\
\text { than } \mathrm{Fe}^{2+} \text {. }\end{array}$ & $\begin{array}{l}\text { Slow process. } \\
\text { Limited applicability in environmental } \\
\text { technologies. }\end{array}$ \\
\hline & $\begin{array}{l}\mathrm{H}_{2} \mathrm{O}_{2} / \mathrm{Fe}^{2+} / \mathrm{UV} \\
\text { (photo-Fenton) }\end{array}$ & $\begin{array}{l}\text { The addition of UV light } \\
\text { improves the degradation rate. } \\
\text { Cyclic process, regeneration of } \\
\text { ferrous ion }\left(\mathrm{Fe}^{2+}\right) \text { by } \\
\text { photo-reduction of ferric ions. } \\
\text { Sludge formation is minimal. }\end{array}$ & $\begin{array}{l}\text { The efficiency of the reaction depends on } \\
\text { the lamp power and type of light. }\end{array}$ \\
\hline & Electro-Fenton & $\begin{array}{l}\text { Efficient for complete } \\
\text { degradation and mineralization }\end{array}$ & Optimal at strong acid pH ( $\mathrm{pH}$ 2.8-3.5). \\
\hline & Photoelectro-Fenton & of synthetic and real wastewaters. & \\
\hline \multirow{2}{*}{$\begin{array}{l}\text { Heterogeneous } \\
\text { photocatalysis }\end{array}$} & $\begin{array}{l}\mathrm{TiO}_{2} / \mathrm{ZnO} / \mathrm{CdS}+\mathrm{UV} \\
\mathrm{TiO}_{2} / \mathrm{UV} / \mathrm{H}_{2} \mathrm{O}_{2}\end{array}$ & \multirow{2}{*}{$\begin{array}{l}\text { More efficient than } \\
\text { homogeneous catalysis. } \\
\text { High availability and } \\
\text { cost-effectiveness of } \\
\text { photocatalysts. } \\
\text { Non-selective catalytic activity. } \\
\text { Applicability to a wide pH range. } \\
\text { Does not generate sludge or } \\
\text { toxic compounds. }\end{array}$} & \multirow{2}{*}{$\begin{array}{l}\text { Limited application to } \\
\text { inorganic environments. } \\
\text { Low chemical stability of } \\
\text { the photocatalyst. } \\
\text { High-energy consumption. } \\
\text { Rapid deactivation/poisoning of the } \\
\text { surface-active site. } \\
\text { Spent photocatalyst is disposed of as } \\
\text { secondary solid waste. }\end{array}$} \\
\hline & $\begin{array}{l}\mathrm{O}_{3} / \text { catalyst/light } \\
\text { (Photocatalytic Ozonation) }\end{array}$ & & \\
\hline
\end{tabular}

In general, homogeneous processes, such as electrochemical and Fenton, require less energy than heterogeneous processes. However, these processes are selective and lead to the formation of contaminants, such as iron oxides. Another limitation of homogeneous processes, such as in chemical and photochemical systems $\left(\mathrm{H}_{2} \mathrm{O}_{2} / \mathrm{Fe}^{3+}\right.$ and $\left.\mathrm{H}_{2} \mathrm{O}_{2} / \mathrm{Fe}^{3+} / \mathrm{UV}\right)$, involves their restricted applicability in environmental technologies. In addition, they have high operating costs. In terms of efficiency, the heterogeneous processes are more efficient, 
and in some cases can reach the mineralization of the pollutant, which, in many cases, is not achieved in homogeneous processes, mainly in ozonation and $\mathrm{H}_{2} \mathrm{O}_{2} / \mathrm{UV}$.

Homogeneous oxidative processes are highly dependent on the dosage of the reagent to the medium. Those using $\mathrm{H}_{2} \mathrm{O}_{2}$ will have to dose a specific amount to achieve a higher percentage of removal, which will depend on the initial concentration of the dye and the response to oxidation. Often, the amount to be dosed is measured by the theoretical stoichiometric ratio between $\mathrm{H}_{2} \mathrm{O}_{2}$ and COD. However, it is necessary to analyze the negative effects of the treatment before establishing the dilution ratio. In addition, the excessive use of $\mathrm{H}_{2} \mathrm{O}_{2}$ generates a residual that contributes to the increase in COD or acts as a scavenger of the hydroxyl radicals generated, slowing down the oxidation rate [6]. Additionally, it affects the microbial activity [56] and, consequently, the efficiency of the biological degradation that is usually employed as a post-treatment to the selected AOP. For all these reasons, the $\mathrm{H}_{2} \mathrm{O}_{2}$ dosage must be previously adjusted through laboratory-scale studies, so that the exact amount to be used in the effluent in question is obtained [57]. Homogeneous catalysts in AOPs are easy to apply, low cost, do not require complex processes to obtain them, present low resistance to mass transfer, facilitate the treatment of contaminants [58,59], and achieve complete degradation and partial mineralization of the dyes [60-63]. However, as they are in the same phase, their separation from the reaction medium with conventional processes is difficult and the cost per treatment rises [64].

Given the problems presented by homogeneous AOPs, the interest in heterogeneous processes is increasing (due to the generation and use of efficient catalysts) $[65,66]$. Based on this, a search was performed in the Scopus database (the year 2010-2021) on the application of heterogeneous AOPs for the degradation of food dyes (Figure 1). A total of 10,886 manuscripts were reported, where approximately 34\% (3691 documents) corresponded to photocatalytic processes without the use of nanocatalysts. This shows an increase ( $66 \%$ of the total) in the use of nano-photocatalysts in the last decade.

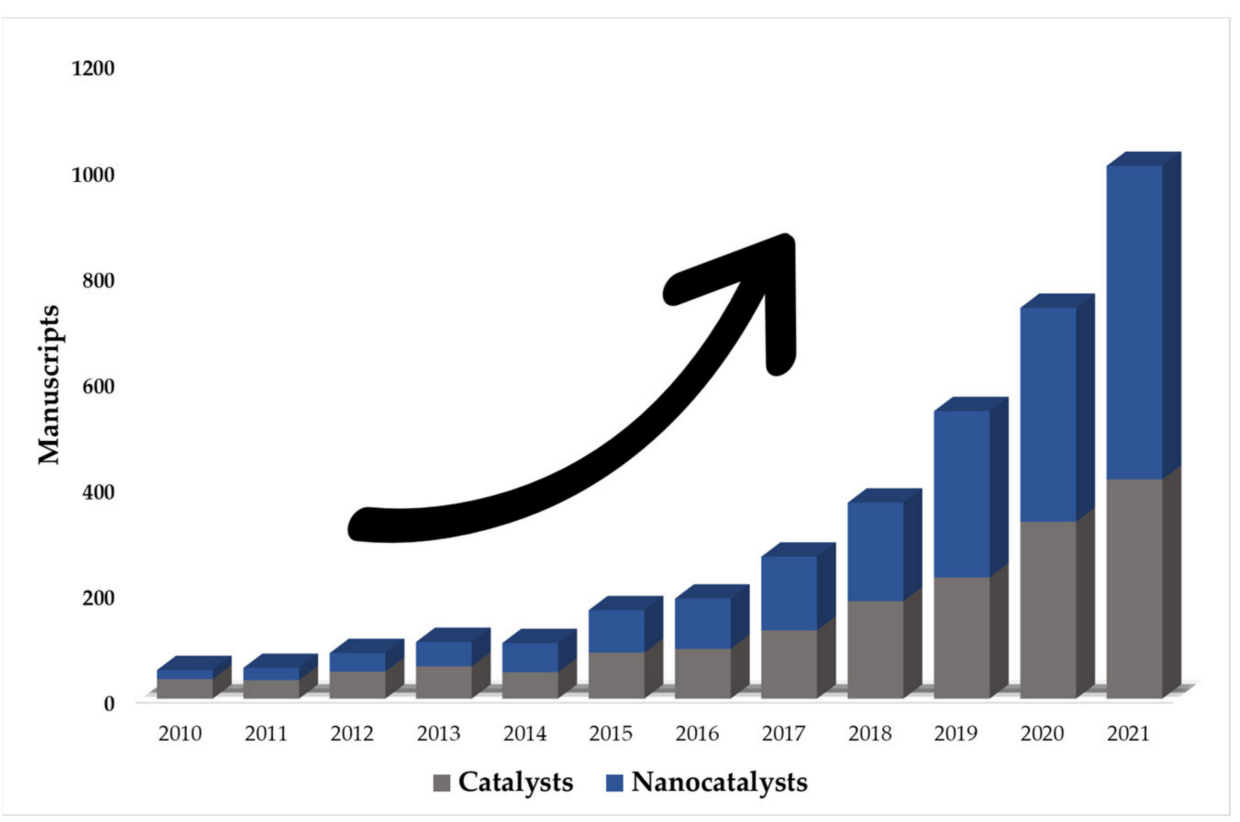

Figure 1. The number of publications of photocatalytic processes using catalysts and nanocatalysts. (Source: Scopus database with keywords search: photocatalysis, nano, degradation, and food dyes).

These heterogeneous photocatalytic processes are already recognized as 'green' and viable strategies for environmental problems [11,67-69]. The basic mechanism of this process is the adsorption of light photons and the formation of electron holes [70]. To achieve the degradation of dyes, these processes generally involve three active agents- 
hydroxyl radicals $\left({ }^{\circ} \mathrm{OH}\right)$, superoxide anion radicals $\left({ }^{\circ} \mathrm{O}_{2}{ }^{-}\right)$, and holes $\left(h^{+}\right)$that participate in a series of photocatalytic reactions, described as follows:

$$
\begin{gathered}
\text { Catalyst }+h v \rightarrow \text { Catalyst }{ }^{*}\left\{\left(e_{\mathrm{CB}}^{-}\right)+\left(h_{V B}^{+}\right)\right\} \\
h_{V B}^{+}+\mathrm{H}_{2} \mathrm{O} \rightarrow \mathrm{H}^{+}+{ }^{\circ} \mathrm{OH} \\
2 h_{V B}^{+}+2 \mathrm{H}_{2} \mathrm{O} \rightarrow \mathrm{H}^{+}+\mathrm{H}_{2} \mathrm{O}_{2} \\
\mathrm{H}_{2} \mathrm{O}_{2} \rightarrow 2^{\circ} \mathrm{OH} \\
e_{\mathrm{CB}}^{-}+\mathrm{O}_{2} \rightarrow{ }^{\circ} \mathrm{O}_{2}^{-} \\
e_{\mathrm{CB}}^{-}+\mathrm{O}_{2} \rightarrow{ }^{\circ} \mathrm{O}_{2}^{-} \\
\mathrm{O}_{2}^{-}+2^{\circ} \mathrm{OH}+\mathrm{H}^{+} \rightarrow \mathrm{H}_{2} \mathrm{O}_{2}+\mathrm{O}_{2} \\
\mathrm{H}_{2} \mathrm{O}_{2} \rightarrow 2^{\circ} \mathrm{OH} \\
\text { Dye }+{ }^{\circ} \mathrm{OH} \rightarrow \text { Degradation of Dye } \\
\text { Catalyst }=\text { semiconductor }
\end{gathered}
$$

However, most of the information presented in the specialized literature is focused on the degradation of dyes and their derivatives in the textile industry using these oxidative processes, without placing greater emphasis on food dyes, which are also part of the organic pollutants that cause alterations to the ecosystem, in general, when present in untreated effluents of these industries [43].

\section{Advances in Heterogeneous Advanced Oxidation Processes}

\subsection{Catalysts in AOPs for Removal of Food Dyes}

The use of catalysts for the degradation of organic and inorganic pollutants in effluents has increased in recent years. Catalysts have been widely studied for the degradation of dyes, so a wide range of them have been developed, such as metals, metal oxides, semiconductors, metal-organic frameworks (MOF), even quantum dots, dendrimer with magnetic core, among others [20]. Several strategies were developed for their syntheses, such as coprecipitation, flame hydrolysis, microwave radiation, impregnation, sol-gel method, hydrothermal and solvothermal techniques, chemical vapor deposition method, electrodeposition method, and electrospinning, among others [71,72].

Titanium dioxide $\left(\mathrm{TiO}_{2}\right)$ is one of the most widely applied semiconductor materials in the field of photocatalysis. As such, it is the catalyst of choice for decomposing dyes into mineralized products due to its abundance, chemical stability, good optical transparency, high refractive index, non-toxic nature, and low cost [20]. Khiabani et al. [73] analyzed the photodegradation process of Brilliant Blue FCF by adding $\mathrm{TiO}_{2}$ under UV irradiation. It was shown that, the most important oxidative pathways for the degradation of this dye involved the loss of para-methylbenzenesulfonic acid (MBSA) groups and ethyl groups adjacent to amines. On the other hand, the effectiveness of $\mathrm{TiO}_{2}$ can be improved when combined with other compounds, as performed by Rajamanickam et al. [74], who synthesized a $\mathrm{SeO}_{2} / \mathrm{TiO}_{2}$ composite photocatalyst to degrade the dye Sunset Yellow under solar irradiation in an aqueous solution. The results indicated that this combination was very effective, achieving a degradation of the dye in the order of $96.6 \%$.

However, studies that are more recent show that $\mathrm{TiO}_{2}$ has properties that are harmful to human health, leading researchers to reflect on the use of this in AOPs, and to search for new catalyst alternatives. In addition, it was shown that relatively high doses are required to achieve complete degradation - and even to achieve mineralization of the simplest compounds in a shorter time [75].

Other semiconductors, such as $\mathrm{ZnO}, \mathrm{CdS}, \mathrm{WO}_{3}$, and $\mathrm{Fe}_{2} \mathrm{O}_{3}$, have been used in different studies, but to a lesser extent since they are heavy metals that can generate secondary contaminants [76]. Sudrajat et al. [77] developed and characterized an $\mathrm{N}$-doped $\mathrm{ZrO}_{2}$ pho- 
tocatalyst $\left(\mathrm{N}-\mathrm{ZrO}_{2}\right)$ by thermal decomposition of the zirconium hydroxide-urea complex. This photocatalyst presented better catalytic activity (with a decolorization of $67.2 \%$ ) than pure $\mathrm{ZrO}_{2}$ in degrading amaranth dye under visible or $\mathrm{UV}$ light irradiation at neutral $\mathrm{pH}$, initial dye concentration of $10 \mathrm{mg} \mathrm{L}^{-1}$, and catalyst concentration of $1 \mathrm{~g} \mathrm{~L}^{-1}$. However, as an alternative, it was demonstrated that, with the use of UVA light at $3.5 \mathrm{~W} \mathrm{~m}^{-2}$ at similar conditions, the complete elimination of the amaranth dye was achieved, without generating toxic derivatives.

Despite the advantages of applying semiconductor catalysts to increase the effectiveness of treatments, the routes to obtain them are complex. Moreover, they require UV irradiation to photo-decompose a dye due to their large band gaps, which increase the cost of the treatment [20,78]. For this reason, several studies have opted for doping with transition metals to extend the adsorption band to the visible region, as they exhibit excellent photocatalytic activity [79-81]. On the other hand, there is an emerging trend of the combination of photocatalytic processes with electrochemical advanced oxidation processes (EAOPs), to improve the degradation performance by the adequate formation of reactive species. For this purpose, photoactive electrodes (also called photoanodes or bifunctional anodes) are applied, which serve as electrodes as well as photocatalysts. However, technology based on electro-oxidation, in some specific cases, has the disadvantage of the possible formation of recalcitrant by-products.

In general terms, this process can cause poisoning effects due to the release of metal particles or microparticles and produce by-products that are more toxic than the primary pollutant, so it is necessary to evaluate the toxicity of the treated effluent, especially if the objective is not to achieve complete mineralization. Therefore, it is necessary to use new economical and environmentally-friendly methods, such as the so-called green catalysts [82-85], or nanocatalysts that improve the efficiency of advanced oxidative processes in the form of nanoparticles, nanotubes, nanospheres, and nanofibers $[75,86,87]$.

\subsubsection{Nanocatalysts}

In recent decades, nanometer-sized materials $(<100 \mathrm{~nm})$ have been considered promising options, as they can adopt different shapes, sizes, structures, and improve the catalytic activity, selectivity, and stability of the system $[14,88,89]$. Unlike catalysts, nanocatalysts, due to their nanosize, have a larger surface area, allowing for better surface-volume interaction and, therefore, greater diffusion of reagents and products. Sometimes, to improve the efficiency of the process, these nanoparticles are dispersed on support, coupled, or doped with metals or adsorbents that have high porosity. The most commonly used support materials are zeolites, activated carbon, silicon film, and hybrid materials $[15,90]$. To ensure the stability of the nanoparticles, their synthesis must be carried out correctly since, when they bind ineffectively to the support, they are easily detached after the first use and washing [91].

The characteristics that make them potential tools for the removal of food dyes in wastewater include low sludge production and the possibility of reuse through regeneration methods integrated into the system [92].

Figure 2 shows several of the different known structures of nanocatalysts that can mediate the degradation of food dyes.

A wide variety of nanocatalysts exist for the degradation of pollutants in aqueous solutions from electrocatalysts, Fenton-based catalysts, and catalysts with antimicrobial characteristics [89]. For example, Thakur et al. [93] synthesized gelatin-Zr (IV) phosphate nanocomposites (GT/ZPNC) to degrade Fast Green dye, achieving a photocatalytic degradation performance of $89.91 \%$ over 5 h; even the antimicrobial activity of GT /ZPNC against E. coli was measured. Karkmaz et al. [94] synthesized cadmium vanadate nanostructures using the sol-gel auto-combustion process, achieving a $67 \%$ photocatalytic degradation of the dye erythrosine. On the other hand, Orooji et al. [95] obtained, for the first time, $\mathrm{Gd}_{2} \mathrm{ZnMnO}_{6} / \mathrm{ZnO}$ nanocomposites (GZMO/ZnO NC) by employing the sol-gel auto combustion technique using grape or coffee syrup as green fuel, obtaining a product with 
a forbidden band of about $3.27 \mathrm{eV}$ and efficient for dye removal. This study showed a superior photocatalytic activity towards the degradation of anionic dyes (erythrosine) by $73.8 \%$.

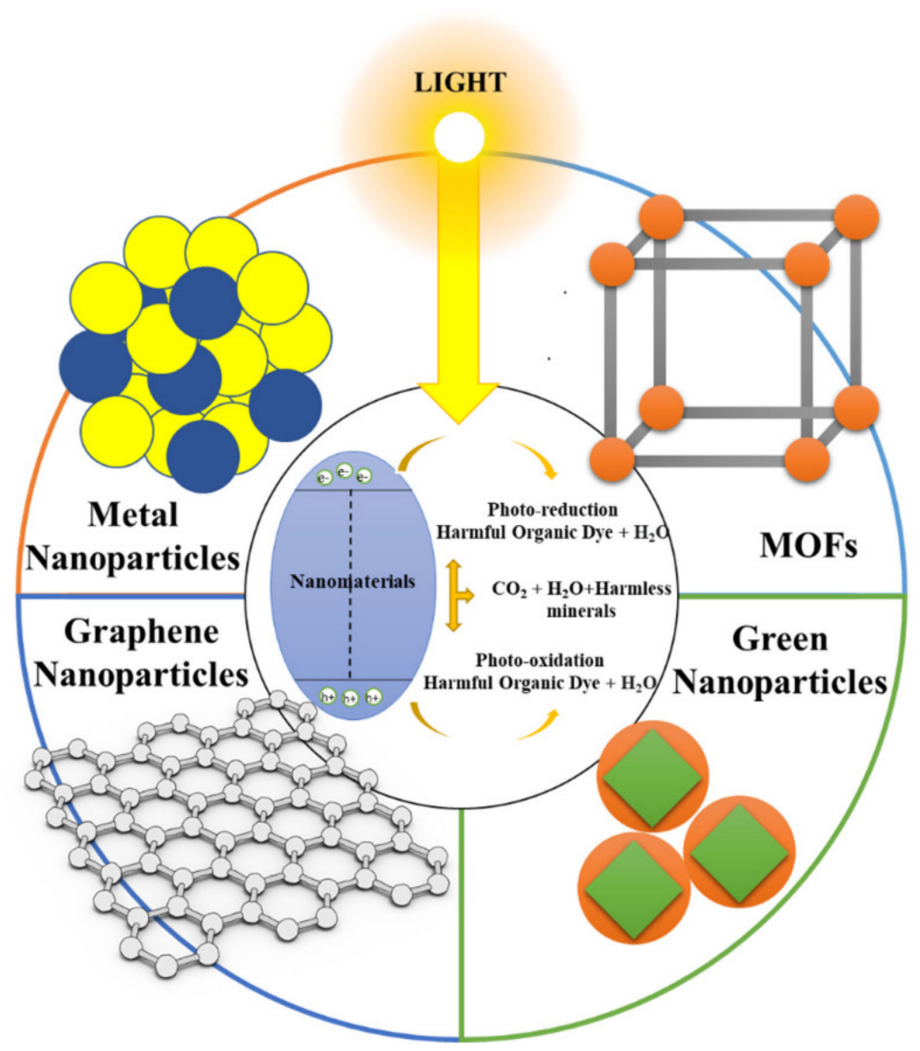

Figure 2. Schematic representation of the main nanomaterials used as nanocatalysts in AOPs for the degradation of food dyes.

Each nano-photocatalyst exhibits particle sizes and shapes that affect its reaction performance and, at the same time, the morphology of nanoparticles depends on their chemical environment or presence of adsorbates [96]. Controlling morphology allows selective exposure of a larger portion of reactive facets to enrich and fine-tune catalytically active sites [97]. Nanocatalysts with complex morphologies, such as cubes, prisms, stars, or rods exhibit enhanced adsorption due to their multipolar resonances compared to the spherical nanostructures [98]. Bahadori et al. [99] obtained pure and Fe-doped methyl-imogolite nanotubes by ion-exchange catalyzing photo-Fenton reaction in the aqueous phase for the degradation of tartrazine. Tests showed that both nanotubes effectively photodegrade the food dye, even tartrazine mineralization is achieved with nanotubes containing $0.70 \mathrm{wt} . \%$ Fe. Darwish et al. [100] synthesized PVP-coated cadmium sulfide (CdS) nanoparticles using polyol with ethylene glycol, a facile method guaranteed to decrease photo corrosion. CdS exhibits better photocatalytic functions than $\mathrm{TiO}_{2}$ by rapidly generating electron-hole pairs by photoexcitation. The researchers evaluated the efficiency of nanoparticles obtained by photocatalytic degradation of tartrazine under UVC irradiation and visible light, achieving complete removal of the dye after $90 \mathrm{~min}$. Nazim et al. [101] synthesized porous $\mathrm{CuO}$ nanosheets using $\mathrm{NaBH}_{4}$ as a reducing agent in an aqueous medium at room temperature. It achieved an optical energy band gap of $21.92 \mathrm{eV}$, resulting in excellent photocatalytic efficiency to degrade the food dye Allura Red AC by $96.99 \%$ in 6 min. Table 3 provides a summary of several studies performed for the degradation of food dyes from the use of different types of nanocatalysts in AOPs. 
Table 3. Nanomaterials as catalysts in AOPS applied to degrade food dyes.

\begin{tabular}{|c|c|c|c|c|c|c|c|c|c|c|}
\hline Process & Dye & $\mathrm{C}_{0}$ & Catalyst & Dose C & Preparation Method & $\mathbf{t}$ & $\mathbf{R}$ & D & R.C & Ref. \\
\hline Fenton photooxidation & Tartrazine & 50 & $\mathrm{Cu}-(\mathrm{BiOCl})$ with $\mathrm{H}_{2} \mathrm{O}_{2}$ & 0.5 & Coprecipitation & 90 & Visible & 91 & 1 & [87] \\
\hline Photocatalytic & Tartrazine & 10 & $8 \% \mathrm{TiO}_{2}(\mathrm{PVDF}-\mathrm{TrFE})$ & 0.9 & - & 300 & Solar & 78 & 2 & [91] \\
\hline Photocatalytic & Tartrazine & 10 & $\mathrm{Cu}-\left(\mathrm{mpg}-\mathrm{C}_{3} \mathrm{~N}_{4}\right)$ & 0.5 & Pyrolysis & 240 & UV & 81.9 & - & [102] \\
\hline Adsorption-photocatalysis & Tartrazine & 10 & Ze-nanZnO & 0.1 & Chemical precipitation & 900 & UV & 87 & - & [103] \\
\hline Photocatalytic & Tartrazine & 16 & $\mathrm{CuO}$ & 0.25 & Chemical precipitation & 240 & Visible & 90 & - & [104] \\
\hline Photo-Fenton & Tartrazine & 40 & MeIMO-Fe 0.025 with $\mathrm{H}_{2} \mathrm{O}_{2}$ & 0.25 & Ion exchange & 240 & UV & 100 & 5 & [99] \\
\hline Photocatalytic & Tartrazine & 25 & $\mathrm{ZnO}$ doped $\mathrm{Ni}$ & 0.1 & Hydrothermal & 60 & UV & 98.2 & - & [105] \\
\hline Photocatalytic & Tartrazine & 10 & $\mathrm{C}_{3} \mathrm{~N}_{4} / \mathrm{ZnO} @ \alpha-\mathrm{Fe}_{2} \mathrm{O}_{3}$ & 0.5 & Direct pyrolysis and sol-gel & 35 & UV & 99.34 & 3 & [106] \\
\hline Photocatalytic & Tartrazine & 20 & Benzoic acid $/ \mathrm{TiO}_{2}$ & 0.1 & - & 70 & Visible & 99.08 & 4 & [107] \\
\hline Photocatalytic & Tartrazine & 50 & $\mathrm{CuCr}_{2} \mathrm{O}_{4}$ & 0.5 & Auto-combustion & 120 & Visible & 99.6 & 4 & [108] \\
\hline Catalytic & Tartrazine & 100 & $\mathrm{AgNP}$ & $60 \mathrm{ug}$ & Green route & 15 & - & 26 & 6 & [109] \\
\hline Photocatalytic & Tartrazine & 25 & semiconductors in $\mathrm{Ag}_{3} \mathrm{PO}_{4}$ & 0.025 & - & 120 & Visible & 100 & - & [110] \\
\hline Heterogeneous Fenton & Tartrazine & 50 & $\mathrm{Fe}_{2} \mathrm{O}_{3} \cdot \mathrm{SiO}_{2}$ & 0.5 & Easy impregnation & 80 & - & 98.5 & 5 & [112] \\
\hline Catalytic & Tartrazine & 25 & $\mathrm{Al}_{2} \mathrm{O}_{3}$ doped with cobalt & 0.025 & Electrolytic oxidation by plasma & 180 & - & 100 & 5 & [113] \\
\hline Photocatalytic & Tartrazine & 10 & TPt-GO & 0.2 & Chemical-thermal & 180 & Solar & 96.23 & - & [67] \\
\hline Photocatalyst & Tartrazine & $50 \mathrm{mg} / \mathrm{L}$ & $\mathrm{NP} \mathrm{TiO}_{2}$ & 0.5 & Sol-gel & 220 & UV & 83 & 1 & [114] \\
\hline Photocatalyst & Tartrazine & 10 & $\mathrm{Fe}_{2} \mathrm{O}_{3}(\mathrm{MF})$ & 0.6 & & 25 & Visible & 97.1 & 5 & [115] \\
\hline Photocatalytic & Erythrosine & 5 & $\mathrm{DyVO}_{4}$ & 0.05 & Sonochemical & 180 & UV & 88 & 5 & [116] \\
\hline Photocatalytic & Erythrosine & 20 & Graphene -NCs & 0.02 & Ecological sol-gel & 50 & UV & 88.2 & - & {$[70]$} \\
\hline Photocatalytic & Erythrosine & 1.2 & $\mathrm{Nd}_{2} \mathrm{Sn}_{2} \mathrm{O}_{7-} \mathrm{Nd}_{2} \mathrm{O}_{3}$ & 0.05 & Ecological synthesis & 60 & UV & 96 & 8 & [117] \\
\hline Photocatalytic & Erythrosine & 45 & $\mathrm{Cd}_{2} \mathrm{~V}_{2} \mathrm{O}_{7}$ & 0.05 & Sol-gel & 90 & UV & 67 & 3 & [118] \\
\hline Photocatalytic & Erythrosine & 10 & AuNPs@ ZnO & 0.05 & Chemical hydrothermal & 30 & UV & 100 & 6 & [119] \\
\hline Photocatalytic & Erythrosine & 20 & $\mathrm{NiS}_{2}$ & 0.02 & Hydrothermal & 75 & UV & 57 & - & [120] \\
\hline Photocatalytic & Erythrosine & 1.5 & $\mathrm{Dy}_{2} \mathrm{Ce}_{2} \mathrm{O}_{7}$ & 0.06 & Green Synthesis & 70 & Visible & 91.4 & 8 & [121] \\
\hline
\end{tabular}


Table 3. Cont.

\begin{tabular}{|c|c|c|c|c|c|c|c|c|c|c|}
\hline Process & Dye & $\mathrm{C}_{0}$ & Catalyst & Dose C & Preparation Method & $\mathbf{t}$ & $\mathbf{R}$ & D & R.C & Ref. \\
\hline Photocatalytic & Erythrosine & 8 & $\mathrm{NiFe}_{2} \mathrm{O}_{4} / \mathrm{SiO}_{2} / \mathrm{Au}(\mathrm{NiFe} / \mathrm{Si} / \mathrm{Au})$ & 0.2 & Sonochemical & 80 & UV and Visible & 97.3 & 7 & [122] \\
\hline Sonocatalytic & Brilliant blue & 396 & $\mathrm{WO}_{3}-\mathrm{ZnO}$ & 0.2 & Sonochemical & 40 & Ultrasonic & 90 & 6 & [123] \\
\hline Photocatalytic & Brilliant blue & 25 & Chlorine & $0.6 \mathrm{Mm}$ & - & 30 & UV & 95 & - & [124] \\
\hline Photocatalytic & Brilliant blue & 25 & semiconductors in $\mathrm{Ag}_{3} \mathrm{PO}_{4}$ & 2.5 & - & 120 & Visible & 90 & - & [110] \\
\hline Photocatalytic & Amaranth & 25 & $\mathrm{ZnO}: \mathrm{Ag} 1 \%$ & 0.16 & Electrospinning & 600 & Visible & 98.4 & - & [68] \\
\hline Photocatalytic & Amaranth & 25 & ZnO: Ag 1\% & 0.16 & Electrospinning & 600 & UV & 95.9 & - & [68] \\
\hline Photocatalytic & Amaranth & 30 & superporous $\mathrm{TiO}_{2}$ & 0.3 & Sol-gel & 15 & UV & 95.6 & 5 & [125] \\
\hline Photocatalytic & Amaranth & 25 & $\mathrm{ZnO}$ decorated with $\mathrm{Ag}_{2} \mathrm{O}$ & 1 & Ultrasound-assisted precipitation & 30 & Visible & 94 & - & [126] \\
\hline Photocatalytic & Amaranth & 12 & TPt-GO & 0.2 & Chemical-thermal & 180 & Solar & 99.56 & - & [67] \\
\hline Photocatalytic & Amaranth & 50 & MIL-N catalyzed oxone & 0.1 & - & 30 & Visible & 100 & - & [127] \\
\hline Catalytic & Amaranth & 50 & (MOF) Fe, MIL-101 & 0.2 & Schiff's base reaction & 60 & - & 100 & 5 & [128] \\
\hline Catalytic & Amaranth & 50 & Bimetallic Co/Fe nanoparticles & 0.05 & Carbonization & 20 & - & 100 & 5 & [129] \\
\hline Photocatalytic & Sunset Yellow & 10 & $\mathrm{P} 90 / \mathrm{CN}$ at $40 \%$ & 0.1 & Sonication & 5 & Solar simulated & 98.8 & - & [130] \\
\hline Sonochemical oxidation & Sunset Yellow & 50 & peroxymonosulfate $/ \mathrm{CuFe}_{2} \mathrm{O}_{4}$ & 0.025 & Coprecipitation & 30 & Ultrasonic & 95.8 & - & [131] \\
\hline Photocatalytic & Sunset Yellow & 10 & Ailanthus excelsa Roxb & 7 & Green synthesis & 30 & UV & 55 & - & [132] \\
\hline Photocatalytic & Sunset Yellow & 40 & Selenium NP-Drumstick & 0.3 & Green synthesis & 180 & Solar & 83.8 & - & [133] \\
\hline photoelectron-Fenton & Sunset Yellow & 100 & $\mathrm{NP}$ de $\mathrm{Fe}_{3} \mathrm{O}_{4}$ & 0.25 & Coprecipitation & 90 & Solar & 100 & 8 & [134] \\
\hline Photocatalytic & Fast green & 10 & Pp-16@ Ag/AgCl(1:40) & 0.1 & In situ polymerization & 20 & UV & 99 & 4 & [135] \\
\hline Photocatalytic & Fast green & 30 & $\mathrm{OG} / \mathrm{La}_{2} \mathrm{O}_{3} / \mathrm{ZrO}_{2}$ & 0.05 & Coprecipitation & 90 & Visible & 89 & 5 & [136] \\
\hline Photocatalytic & Brilliant green & 50 & $\mathrm{NiO} / \mathrm{CuO}$ & 0.09 & - & 60 & Solar & 82 & 3 & [137] \\
\hline Photocatalytic & Malachite green & 0.73 & $\mathrm{AlBc} @ \mathrm{La} / \mathrm{Cu} / \mathrm{Zr}$ & 0.1 & Microwave & 240 & Solar & 94 & 5 & [138] \\
\hline Photocatalytic & Indigo carmine & 10 & CdO nanowires & - & Mild chemical pathway & 270 & Visible & 30 & - & [139] \\
\hline Photocatalytic & Indigo carmine & 20 & $\mathrm{Pd}-\mathrm{ZnS} / \mathrm{rGO}$ & 1.0 & Co-precipitation & 210 & UV & 100 & - & [140] \\
\hline
\end{tabular}


Table 3. Cont.

\begin{tabular}{|c|c|c|c|c|c|c|c|c|c|c|}
\hline Process & Dye & $\mathrm{C}_{0}$ & Catalyst & Dose C & Preparation Method & $\mathbf{t}$ & $\mathbf{R}$ & $\mathbf{D}$ & R.C & Ref. \\
\hline Photocatalytic & Ponceau 4R & 10 & CdO nanowires & - & Mild chemical pathway & 270 & Visible & 39 & - & [139] \\
\hline Photoelectrochemical & Ponceau 4R & 15 & $\mathrm{ZnCo}_{2} \mathrm{O}_{4} / \mathrm{ZnO}$ & 0.125 & Sol-gel & 220 & Solar & 70 & - & [141] \\
\hline photo-Fenton & Ponceau 4R & 50 & Floating catalyst ZVI supported with LDPE & 0.072 & Thermal fixation & 15 & UV & 100 & 4 & [142] \\
\hline Catalytic & Carmoisine & 100 & $(\mathrm{AgNP})$ & $60 \mathrm{ug}$ & Green route & 15 & - & 48 & 6 & [109] \\
\hline Electrochemical & Carmoisine & 5 & electro-oxidation-plasma electrode BBD & $0.045 \mathrm{Mm}$ & Electro-oxidation-plasma & 60 & - & 100 & - & [143] \\
\hline
\end{tabular}

$\mathrm{C}_{0}$, initial dye concentration (ppm); Dose $\mathrm{C}$, dose catalyst (g/L); $\mathrm{t}$, time of maximum color degradation (min); R, radiation source; $\mathrm{D}$, dye degradation (\%); R.C, nanocatalyst regeneration cycles. 


\subsubsection{Metal Oxide-Based Nanocatalysts}

Oxide-based nanocatalysts are inorganic types that are generally prepared with metals and non-metals, which are widely used for the removal of hazardous pollutants from wastewater. They are characterized by high BET surface area, lower solubility, minimal environmental impact, and absence of secondary pollutants [89]. Metal oxide nanocatalysts are classified into three generations: the first generation is composed of a single component, such as $\mathrm{TiO}_{2}$ and $\mathrm{ZnO}$; the second generation is composed of multiple components in a suspension, e.g., $\mathrm{WO}_{3} / \mathrm{NiWO}_{4}, \mathrm{BiOI} / \mathrm{ZnTiO}$; and finally, the third generation is formed by photocatalysts immobilized on solid substrates $\left(\mathrm{FTO} / \mathrm{WO}_{3}-\mathrm{ZnO}\right.$, Steel $\left./ \mathrm{TiO}_{2}-\mathrm{WO}_{3}\right)$ [20]. There are three natural states of the nanocatalyst, anatase, rutile, and brookite, with anatase being the best nano-photocatalyst, and is usually effective in degrading anionic, cationic dyes, and dyes with different chromophore groups [20,144].

Naik et al. [125] developed super porous $\mathrm{TiO}_{2}$ nanostructures using the sol-gel method to improve the surface area and robust structural porosity of $\mathrm{TiO}_{2}$ anatase, and achieve higher photocatalytic performance without using support material. This research obtained excellent results, exceeding the efficiency of other $\mathrm{TiO}_{2}$ catalysts, in $15 \mathrm{~min}$, degrading $95.6 \%$ of Amaranth dye ( $30 \mathrm{ppm}$ ) using $0.3 \mathrm{~g}$ of the catalyst under UV irradiation. Moreover, this nanocatalyst also showed good stability for 5 cycles. Lamba et al. [126] synthesized and characterized heterostructures of $\mathrm{Ag}_{2} \mathrm{O}$-decorated $\mathrm{ZnO}$ nanowires using the ultrasound-assisted precipitation method. Through photocatalytic reaction processes (Figure 3), photogenerated electron/hole pairs actively participate in the chemical reactions for the generation of superoxide radicals and oxidizing agents, which are responsible for the degradation of the dye. Photocatalytic activity was measured by the degradation of Amaranth dye under visible light irradiation, exhibiting a photocatalytic yield of about $94 \%$ in $30 \mathrm{~min}$. These heterostructures showed a synergistic effect, which was more efficient than pure $\mathrm{ZnO}$ nanowires and $\mathrm{Ag}_{2} \mathrm{O}$ NPs separately, even presenting higher activity under visible light irradiation than commercially available photocatalysts, such as Merck $\mathrm{ZnO}$, $\mathrm{TiO}_{2}-\mathrm{P} 25$, and $\mathrm{TiO}_{2}-\mathrm{PC}-50$.

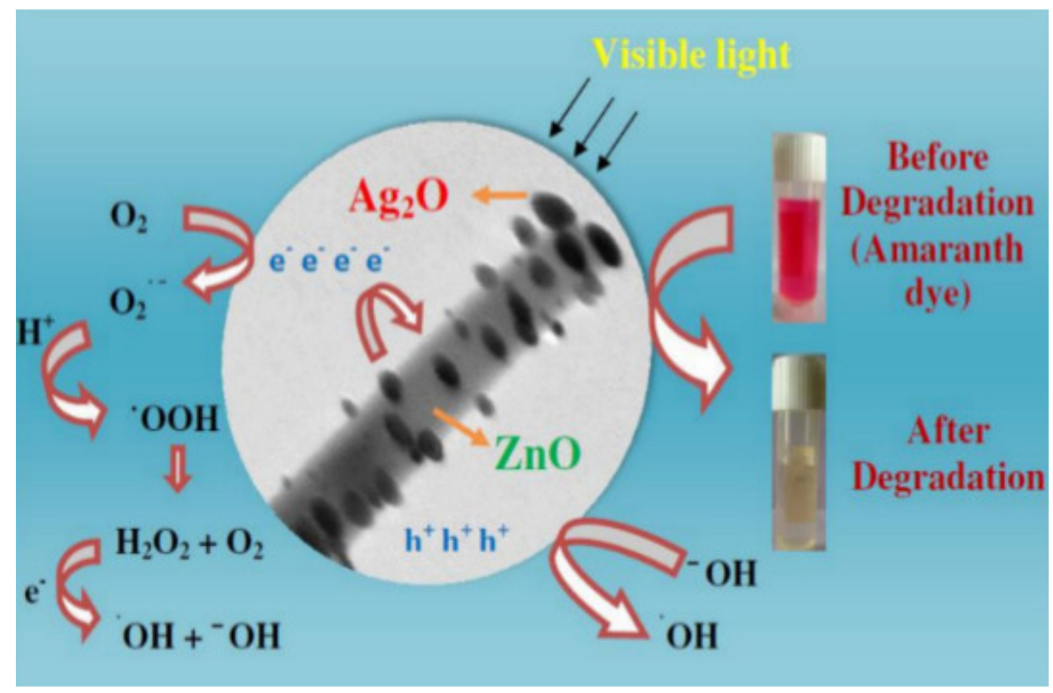

Figure 3. The plausible photocatalytic mechanism for photocatalytic degradation of amaranth dye in the presence of $\mathrm{Ag}_{2} \mathrm{O}$ nanoparticles decorated $\mathrm{ZnO}$ nanorod heterostructures under visible light irradiation. [126].

Aoudjit et al. [91], on the other hand, evaluated the feasibility of using PVDF-TrFE photocatalytic membranes with immobilized $\mathrm{TiO}_{2}$ nanoparticles as a catalyst to degrade tartrazine in a solar photoreactor. A high removal performance of the pollutant $(78 \%)$ was obtained, but a second use under the same experimental conditions showed a reduction of approximately $10 \%$ in degradation efficiency. The causes of loss of efficiency are mainly because not all of the nanoparticles are effectively bound to the polymeric matrix and tend 
to detach from the first use and subsequent washing and/or to a large amount of dye retained on the membrane surface, and the consequent decrease of specific photocatalytic active sites, both reasons becoming the main limitations of immobilized systems.

Alcantara-Cobos et al. [103] prepared zeolite-ZnO nanoparticles (Ze-nanZnO) for a coupled adsorption-photocatalysis process. This coupling obtained lower degradation percentages than pure $\mathrm{ZnO}$ nanoparticles; however, although the degradation of nan $\mathrm{ZnO}$ is higher, the separation process of nanZnO is more complex, making the process more expensive. Finally, Türkyılmaz et al. [105] synthesized and analyzed $\mathrm{ZnO}$ nanostructures doped with $\mathrm{Ni}, \mathrm{Mn}, \mathrm{Fe}$, and $\mathrm{Ag}$, to degrade tartrazine. A maximum degradation of $98.2 \%$ was achieved with $\mathrm{Ni} / \mathrm{ZnO}$ in $60 \mathrm{~min}$. However, applying $\mathrm{Mn}$ and Fe did not achieve good results, which may be due to the coexistence of multivalent ions in the $\mathrm{ZnO}$ host and their highly agglomerated structures on the $\mathrm{ZnO}$ surface.

\subsubsection{Graphene-Based Nanocatalysts}

Graphene-based nano-photocatalysts have covered a wide field for the photodegradation of dyes in water in two phases. The first one consists of adsorption of the dye on the catalyst surface and the second phase corresponds to the ring scission of the dye ring [145]. Graphene-based nano-photocatalysts exhibit high physicochemical stability, large surface area to volume ratio, high mechanical strength, low optical absorbance and density, good thermal conductivity, and excellent electrical conductivity. [145,146]. However, it is advisable to perform the removal of organic contaminants from the aqueous medium through adsorption separations on graphene-based magnetic nanocomposites [145] and optimize the photothermal performance of graphene-based nanocomposites for enhanced photocatalytic activity [147].

On the other hand, combining graphene with metal oxide semiconductors and other particles favors stability and photocatalytic activity. For this, graphene acts as a photostabilizer of the semiconductors and as an electron sink by greatly reducing the recombination rate of the electron-hole pair, resulting in higher conductivity, low cost, higher absorptivity, tunable optical behavior, longevity, and biocompatibility [148].

A good representation of the series of reactions involved in the use of graphene is represented in Figure 4, in which $\mathrm{OH}^{\bullet}$ radicals are produced by holes, and photogenerated electrons produce $\mathrm{O}_{2}{ }^{\bullet-}$, which play an important role in the degradation of the dye.

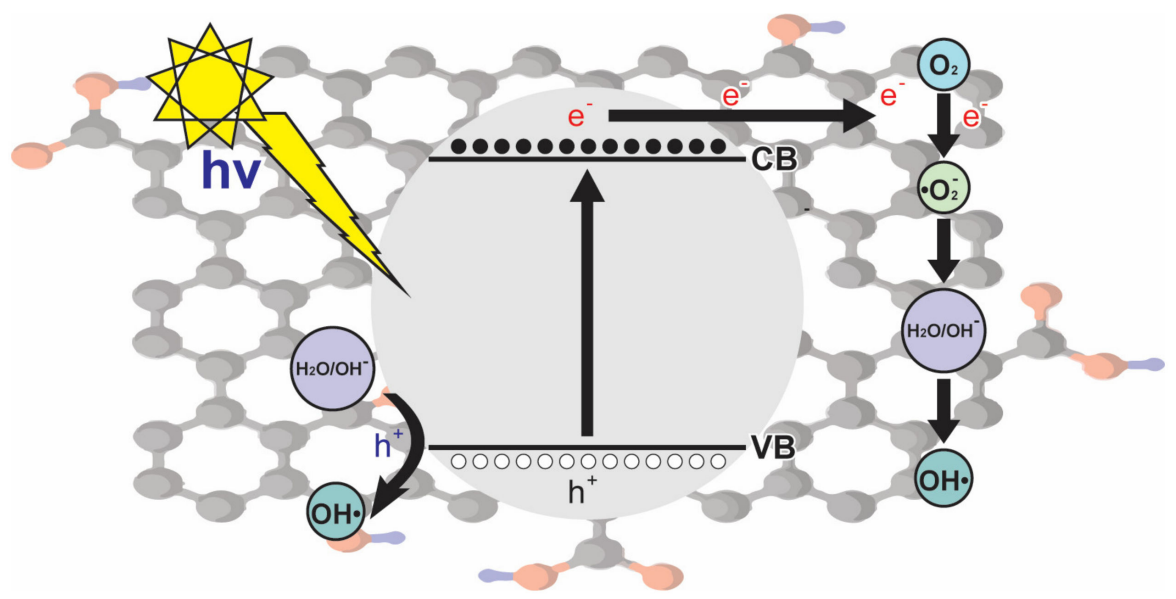

Figure 4. Mechanism of photogenerated charges in reduced graphene oxide.

Under the mechanism depicted in Figure 4, Nada et al. [3] proposed the degradation of tartrazine by using nano-titania-magnetic reduced graphene oxide (MRGT). The synthesis of nanocomposites was performed by loading reduced graphene oxide (RG) with two nanoparticle components consisting of $\mathrm{TiO}_{2}$ and magnetite $\left(\mathrm{Fe}_{3} \mathrm{O}_{4}\right)$ in varying amounts, achieving a dye degradation of more than $95 \%$. 
On the other hand, Agorku et al. [140] achieved Pd-decorated zinc sulfide/reduced graphene oxide nanocomposites (Pd-ZnS/rGO) by the co-precipitation method under UV irradiation. A $100 \%$ photocatalytic degradation of indigo Carmine was achieved by employing a $1.0 \% \mathrm{Pd}$ amount in $\mathrm{ZnS}$, evidencing a good photocatalytic performance due to the synergistic effect of Pd with rGO, small crystal size (crystallite), light absorption intensity, and narrow forbidden band energy (2.0 eV). On the other hand, Rosu et al. [67] developed $\mathrm{TiO}_{2}-\mathrm{Pt}(\mathrm{TPt}), \mathrm{TiO}_{2}-\mathrm{Pt} /$ graphene oxide (TPt-GO), and $\mathrm{TiO}_{2}-\mathrm{Pt} /$ reduced graphene oxide (TPt-rGO) NPs by a combined chemical-thermal method to photodegrade different azo dye structures (amaranth, sunset yellow, and tartrazine) in the presence of UV irradiation and natural sunlight. The efficiency of the photocatalytic activities of the synthesized compounds was demonstrated, especially that of TPt-GO with higher photoactivity under sunlight, removing $99.56 \%$ of amaranth, $99.15 \%$ of sunset yellow, and $96.23 \%$ of tartrazine.

\subsubsection{Metal-Organic Frameworks Synthesized with Nanocomposites}

Metal-organic frameworks (MOFs) are defined as compounds formed by the interaction of metal ions or metal clusters (secondary building units, SBUs) and organic ligands ideal (usually carboxylic acid or nitrogen-containing ligands) for the fabrication of highperformance multifunctional compounds. They are characterized by very good surface areas and high porosity (porous crystalline materials), as well as by dispersed active sites and functionalities within this porosity.

Their ability to act as chemical nanoreactors allows them to synthesize and stabilize, within their channels, a catalytically active species that would otherwise be difficult to access [149-151].

In photodegradation processes, there is a difference between the energies of the light and the band gap. In this case, the mechanism followed by MOFs is that, when the energy promoted by the light source is higher than the energy of the forbidden band, the electrons in the valence band gain energy and are excited to the conduction band, generating a positive hole in the valence band, to then generate reduction and oxidation half-reactions with electrons and holes, respectively. Figure 5 shows the photocatalytic degradation mechanism, where MOFs behaving as semiconductors could be considered potential photocatalysts [152].

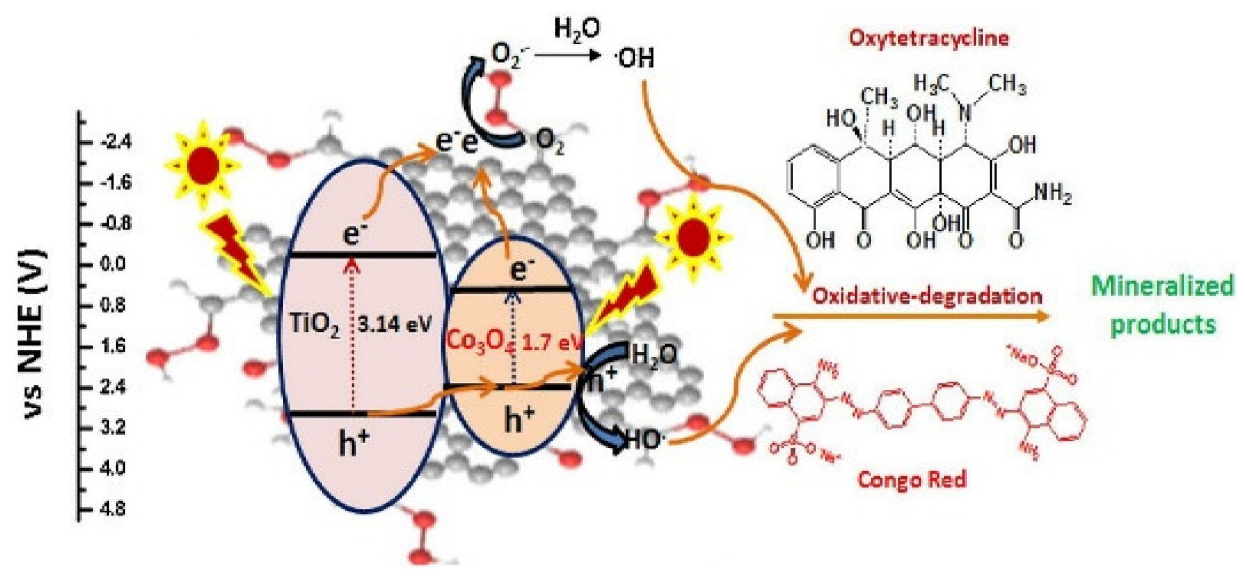

Figure 5. Proposed mechanism for the photocatalytic degradation of organic pollutants by $\mathrm{Co}_{3} \mathrm{O}_{4} / \mathrm{TiO}_{2} / \mathrm{GO}$ nanocomposite [153].

In heterogeneous Fenton reactions, iron-containing metal-organic frameworks (FeMOF) have been heavily used because of their high capacity to generate hydroxyl radicals - $\mathrm{OH}$ and lower photocatalytic activity resulting from the high recombination of electronhole pairs generated [151].

The Materials Institute Lavoisier (MIL) group of metal-organic structures is presented as an efficient alternative in the field of environmental remediation [151]. For example, iron- 
based MOF materials, such as MIL-88A, MIL-53, and MIL-68, are presented as potential photocatalytic tools for dye degradation [154]. Zhang et al. [128] developed for the first time an Fe nanoparticle-containing MOF, MIL-101 as a support to immobilize ferrocene $(\mathrm{Fc})$ chemically. It was employed to degrade amaranth by oxone activated by Fc-MIL. The Fc-MIL presented good catalytic activity and lower activation energy, an advantage that makes it an excellent catalyst to eliminate the toxic amaranth. Since few studies have been conducted for the employment of Fe-based catalysts to activate Oxone in amaranth degradation, Zhang et al. [127] presented a study of Fe nanoparticle-based MOF using oxone catalyzed by MIL-101-NH2, which achieves complete degradation of amaranth dye in $30 \mathrm{~min}$ under visible light irradiation. The catalyst dosage was $100 \mathrm{mg}$, to degrade $50 \mathrm{ppm}$ of amaranth dye. This catalyst could eliminate amaranth dye even in the presence of surfactants. In addition, since it is a heterogeneous catalyst, reusability was tested, showing that it can be used for multiple cycles within $60 \mathrm{~min}$ of degradation.

Meanwhile, Zhang et al. [155] synthesized a catalyst consisting of $\mathrm{TiO}_{2} / \mathrm{mag}-\mathrm{MIL}$ 101 (Cr) nanoparticles under visible light. The magnetic property of this $\mathrm{TiO}_{2}$-loaded composite enhanced its adsorption and photocatalytic efficiency with a forbidden band value of $1.61 \mathrm{eV}$. In addition to being easy to recover, it increases its reusability [129]. In this study, it was used to adsorb and degrade refractory organic compounds, bisphenol-F (BPF) and acid red 1 (AR1), from water, resulting in efficient removal of both compounds. Thus, it is presented as a new tool of semiconductor-MOF nanocatalysts to degrade organic pollutant compounds in water under the use of visible light. However, the microporosity of the MOFs hinders the complete adsorption of larger dye molecules, since the passage to the internal pores or voids of the MOFs is impeded. In addition, there would be a selectivity of charge and/or size, since the MOF-based nanocatalysts would be designed for a specific type of dye, characteristics that are considered unfavorable for the treatment of wastewater by this method containing complex mixtures of dyes [156].

\subsubsection{Nanomaterials Synthesized by Green Technologies}

Although the above processes are considered efficient systems, not all of them are economical and environmentally friendly, because nanomaterials synthesized by conventional routes can involve hazardous and volatile chemicals that even lead to the formation of secondary pollutants [152]. Therefore, it becomes indispensable to find new and efficient methods, with high catalytic activity, are easy to handle, and eco-friendly [14]. In this context, in eras of sustainable development and the application of green chemistry concepts, the most recent alternative studies are nanomaterials synthesized by green technologies or biogenic nanoparticles (BNPs), which are presented as a new tool for photocatalytic water remediation (Figure 6). These BNPs are characterized by possessing a large specific surface area, ion exchange mechanism, unique morphology, high biocatalytic reactivity, efficient regeneration, and colloidal properties, so that they can be separated from effluents by gravity filtration, sedimentation, or the coagulation-flocculation technique [157].

Studies demonstrate the efficiency of these processes for the removal of various food contaminants. Deepika et al. [132] identified the bioactive compounds of Ailanthus excelsa Roxb bark and leaf extract for the removal of synthetic food dyes. The researchers observed that $A$. excelsa bark extract exhibits better photocatalytic activity by degrading $55 \%$ of sunset yellow dye FCF. Likewise, Hassanien et al. [133] synthesized selenium BNPs from Drumstick leaf extracts to evaluate their photocatalytic activity towards the decolorization of sunset yellow dye FCF under solar and UV irradiation, achieving a dye degradation rate of 83.8 and $76.6 \%$, respectively. David and Moldovan [109] proposed the synthesis of silver BNPs (AgNP) by using Viburnum opulus L. fruit extract, which acts as a reducing agent of silver ions and stabilizer of the obtained nanoparticles. The size, morphology, crystalline nature, catalytic ability, and stability of AgNPs were evaluated to remove toxic food dyes, such as tartrazine, carmoisine, and Brilliant Blue FCF in the presence of $\mathrm{NaBH} 4$. These spherical-shaped nanoparticles, with an average diameter of $16 \mathrm{~nm}$, achieved 48 , 
26 , and $97 \%$ degradation of carmoisine, tartrazine, and Brilliant Blue FCF, respectively, in only $15 \mathrm{~min}$.

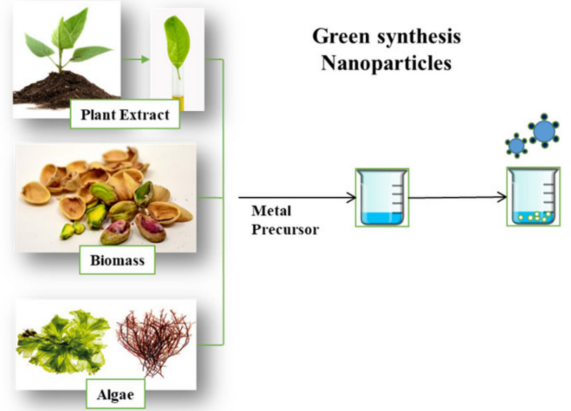

(a)

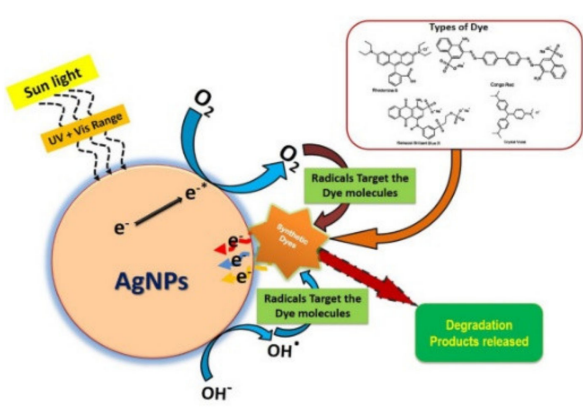

(b)

Figure 6. (a) General representation of the green synthesis of BNPs and (b) reaction mechanism of AgNPs for the degradation of dyes [158].

Although studies on the use of BNPs have increased in recent years (Figure 7a), they are not sufficient in terms of the total number of articles per year. In addition, there is a large difference between the production of BNPs and conventional nanocatalysts. This opens up new lines of research in which the properties of BNPs are not only used in the field of environmental sciences, but also other less-studied areas (Figure 7b).

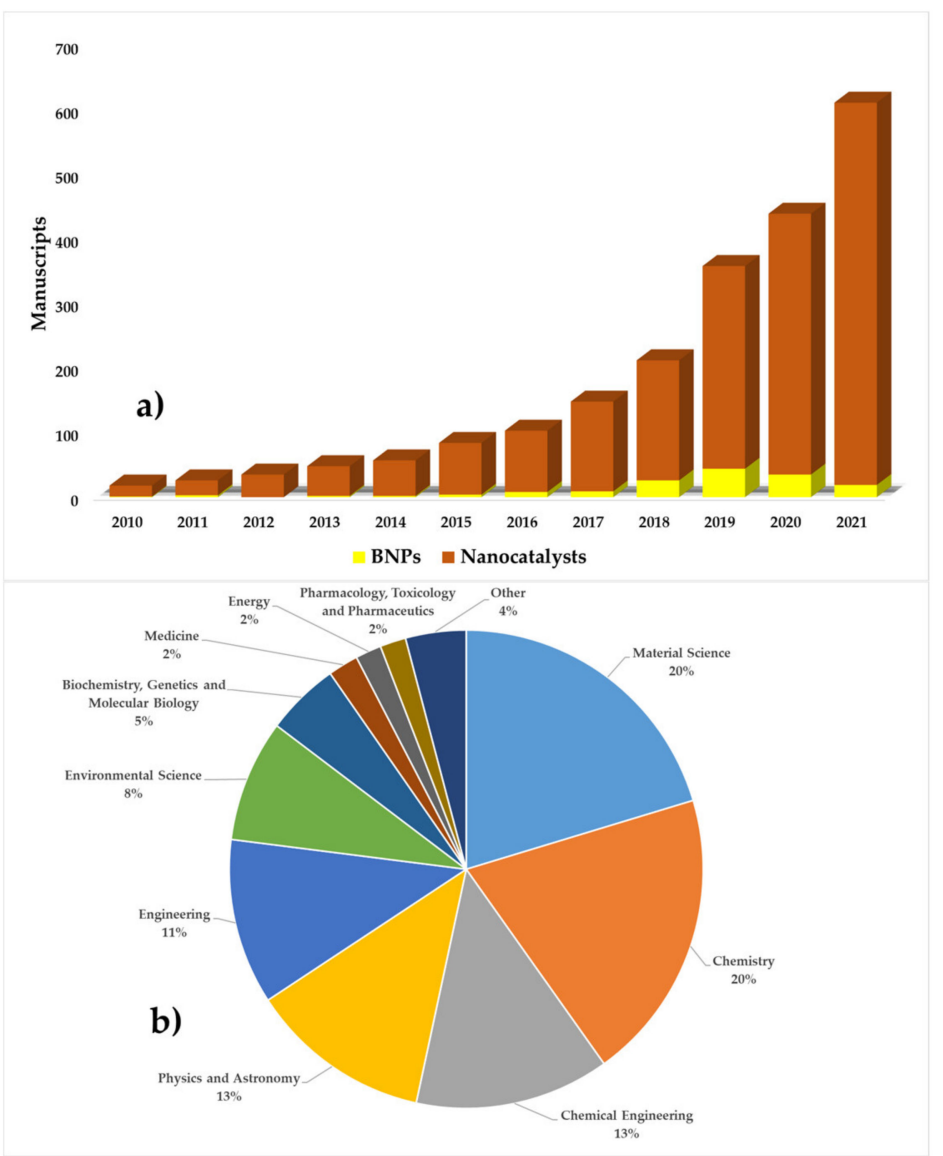

Figure 7. Number of publications on the use of BNP compared to classical nanocatalysts per year (a), BNPs application area (b) (source: Scopus database with searching keywords: "green AND nanocatalysts AND dyes," July 2021). 


\section{Discussion}

The degradation of food dyes through photocatalytic AOPs in wastewater treatment processes has become a promising alternative to conventional methods. This is due to the high degradation yields that this type of technology can achieve. There are several reports in the literature on the oxidation of these compounds using various catalysts and nanocatalysts, based on metal oxides, graphene, MOFs, and biogenic nanoparticles. However, all of these materials—-to achieve maximum operating performance-depend on various parameters, such as the amount and type of catalyst and oxidizing agent, reaction temperature, preparation method, surface area, chemical composition, particle size, morphology, etc. For this reason, semiconductor-mediated photocatalysis of metal oxides $\left(\mathrm{TiO}_{2}, \mathrm{ZnO}, \mathrm{WO}_{3}, \mathrm{CdS}\right)$ presents several limitations, including the difficulty to immobilize powder nanoparticles on substrates acting as support, rapid recombination of photoinduced electron-hole pairs, low activity in the visible region, toxicity to biological systems, and difficulty in enhancing photocatalytic activity (e.g., in degradation processes the efficiency of $\mathrm{TiO}_{2}$ is less than $10 \%$ due to its limited sensitivity to ultraviolet light). For this purpose, evaluations are available that enhance the characteristics of semiconductors through non-metallic doping (N, F, C, S), deposition of noble and transition metals ( $\mathrm{Pt}$, $\mathrm{Pd}, \mathrm{Ag}, \mathrm{Au}, \mathrm{Ru}, \mathrm{Fe}, \mathrm{Ni}$ ), or even coupling with other semiconductors that allow the development of nanocomposites with improvements in their porous structure, surface area, and photocatalytic activity. In addition, the properties of these metals have allowed approaching the coupling of other AOPs, such as photo-assisted electrochemical methods (e.g., photoelectrocatalysis and photoelectro-Fenton), which improve the generation and action of the reactive agents involved in the degradation. However, degradation is much slower, which strongly increases the energy consumption required for total mineralization.

On the other hand, metal oxides can be enhanced in performance when combined with MOFs, increasing degradation performance. However, most research on MOFs has focused on their efficiency as adsorbents for organic pollutants in wastewater; therefore, the number of food dye degradation evaluations using MOFs as nanophotocatalysts is limited. Engineered metal-organic frameworks based on heterogeneous Fe-containing materials (MIL-N) are considered as promising methods to completely degrade food dyes over several reaction cycles. Moreover, the construction of bimetallic or polymetallic MOFs improves the catalytic performance of monometallic MOFs. However, for large scale applications, these structures present drawbacks in their inherent properties and their production, for which several important aspects must be considered, such as availability and cost of materials, treatment procedures, synthesis, activation, yields, decrease in the amount of solvent use, as well as the stability that can be affected by their geometry, metal-ligand bonds, etc.

Another nanomaterial studied is graphene and its derivatives, which show better results when working together with other compounds. Being used as a semiconductor in its pure form, it has disadvantages due to its hydrophobic nature. Graphene oxide (GO) exhibits a higher electrical insulating character due to the presence of functional groups, and it is necessary to reduce the oxygen content by increasing the carbon content in a C:O ratio from 2:1 to 246:1. The compound obtained is called reduced graphene oxide (rGO), and allows the interaction of $\pi$-bonds of organic molecules with the $\pi$-systems of rGO, a property that facilitates the efficient removal of contaminants from water. To reduce electron-hole recombination, graphene oxide is shown as a compound capable of acting as an electron acceptor when combined with metal oxide semiconductors and transition metals (electron traps). One advantage that graphene oxide possesses is the ability to combine oxygen functional groups on its surface with the metal centers of a MOF, so that mass and electron transfer is greatly favored. Although graphene-based nanocomposites can be considered as materials with promising characteristics, the intermediates that may be generated tend to be more toxic than the original organic compounds. Therefore, toxicity testing of remediated waters from AOPs that include graphene-based composites is considered essential. 
Although nanocatalysts are essential for the degradation of pollutants through AOP, one issue of environmental interest has arisen regarding the separation, recovery, and reuse of these nanocomposites once the treatment is complete. Therefore, these materials are generally synthesized with magnetic properties that facilitate the separation and recovery of the material from the aqueous medium, quickly and efficiently. The high magnetic permeability of the particles or compounds with structures formed with Fe allows them to be eliminated and recycled through the application of a suitable magnetic field without causing major effects on the environment. In general terms, before final disposal, it must be ensured that they comply with environmental legislation based on leachability [159]. For this reason, there is currently a trend in the formation of MOFs and their derivatives, since they do not show apparent changes before and after the catalytic reaction, which indicates excellent stability. In addition, the leaching concentration of Fe ions after the reaction is generally in the range of $0.03-2 \mathrm{mg} \mathrm{L}^{-1}$ for MOF catalysts based on Fe NPs, which is below the EU environmental standard $\left(2 \mathrm{mg} \mathrm{L}^{-1}\right)$. On the other hand, modified MOF-based catalysts can reduce the leaching of metal ions by protecting the carbon matrix and core-layer structure [160].

Despite all the advantages manifested by metal oxide, graphene, and MOF NP-based nanocatalysts, they have two limitations in common: (i) the need to couple to other compounds to present improvements in their structures and photocatalytic properties, along with high costs and toxicity synthesis methods, mostly operating at high temperatures and pressures. (ii) The generation of constant secondary contamination, by either the detachment of nanoparticles from the system in function (which end up being incorporated into the aqueous medium) and/or the production of compounds more toxic than the primary contaminant material.

Finally, the scientific community is showing interest in the emergence of the synthesis of nanostructures from biological media, since they are energy efficient, low in cost, easy to scale-up, and do not cause additional damage to the environment, since renewable reagents are used instead of chemical compounds (which act as toxic reduction and dispersing agents). Additionally, they have long reuse cycles without loss of degradation efficiency, and they can be used as stabilizing agents for nanoparticles.

Fungi are favorable options to meet these requirements and, in turn, are the best candidates to synthesize nanocomposites at an industrial level, as they are easily manipulated, secrete large amounts of enzymes necessary for reduction, and present high filamentary tolerance to metals. The use of green synthesis methods may be a way to minimize the risks of secondary contamination.

\section{Conclusions and Prospects}

The present review demonstrates that AOPs have great potential in the degradation treatment of food dyes since AOP chemistry offers several mechanisms for the treatment of this type of organic pollutant. Recent articles demonstrate the growing interest in the application of AOPs for the treatment of these pollutants, for the protection of the environment and human health. Traditionally, most methods used are based on the application of photocatalytic AOPs with micro-sized photocatalysts. However, the current trend is based on the application of nanotechnology for wastewater treatment. The application of nanomaterials has become an opportunity to revolutionize wastewater treatment concepts, favored by their unique properties, which have created a convergence with AOPs. The use of nanomaterials in AOPs has been advantageous because they act catalytically and provide a higher surface area, which significantly increases degradation efficiency. The nanomaterials explored in this review are divided into transition metal, carbon-based, molecular organic (MOF), and are synthesized from green sources (phyto-nanocatalysts). This last classification is the least explored, which emphasizes intensifying this line of materials for their photocatalytic properties and the possibility of fusing with transition metals.

However, despite the excellent properties possessed by these materials, future research should also focus on: 
(i) Reducing the evaluation of the degradation of food dyes from synthetic waters, with more attention on the analysis of real water systems, since several factors that are not considered notably affect the ecosystem or the application of the nanocatalyst in real remediation systems;

(ii) Measuring the toxicity mechanisms of the intermediates generated by the use of nanomaterials for the removal of pollutants in wastewater, and to couple such procedures to advanced analytical chromatography techniques to control the various reaction steps given during the treatment; and

(iii) Controlling and evaluating the type of surface coating, particle size, and residues also generated by the nanomaterials in their different reaction cycles, since even low concentrations of nanoparticles could alter natural processes or cycles and, consequently, affect the microbial community and the ecosystem in general.

In general, it was demonstrated that, whatever the type of nanocatalyst applied, the degradation potential is highly efficient. Studies have been extensively carried out at laboratory or pilot scales. The high costs of production and large-scale availability have become obstacles to large-scale applications. Therefore, the ultimate objective is to develop efficient mechanisms to obtain highly efficient, health-safe, and biodegradable nanomaterials to apply in everyday (and industrial) life.

Author Contributions: Writing—original draft preparation, J.M.N.-M.; writing—review and editing, O.A.E.F., L.A.Z.-I., N.R.M., M.M.M.B.D., L.S.Q.-F., R.J.B.-C., and J.M.R.-D. All authors have read and agreed to the published version of the manuscript.

Funding: This research received no external funding.

Institutional Review Board Statement: Not applicable.

Informed Consent Statement: Not applicable.

Data Availability Statement: The data presented in this study are available upon request from the corresponding author.

Acknowledgments: The authors are very grateful to the Postgraduate Program of Chemical Engineering, Federal University of Paraiba (UFPB), and Universidad Técnica de Manabí.

Conflicts of Interest: The authors declare no conflict of interest.

\section{References}

1. Hussain, S.; Khan, N.; Gul, S.; Khan, S.; Khan, H. Contamination of water resources by food dyes and its removal technologies. In Water Chemistry; Intech Open: London, UK, 2019.

2. Amchova, P.; Kotolova, H.; Ruda-Kucerova, J. Health safety issues of synthetic food colorants. Regul. Toxicol. Pharmacol. 2015, 73, 914-922. [CrossRef] [PubMed]

3. Nada, A.A.; Tantawy, H.R.; Elsayed, M.A.; Bechelany, M.; Elmowafy, M.E. Elaboration of nano titania-magnetic reduced graphene oxide for degradation of tartrazine dye in aqueous solution. Solid State Sci. 2018, 78, 116-125. [CrossRef]

4. Adegoke, K.A.; Bello, O.S. Dye sequestration using agricultural wastes as adsorbents. Water Resour. Ind. 2015, 12, 8-24. [CrossRef]

5. Javaid, R.; Qazi, U.Y. Catalytic oxidation process for the degradation of synthetic dyes: An overview. Int. J. Environ. Res. Public Health 2019, 16, 2066. [CrossRef] [PubMed]

6. Collivignarelli, M.C.; Pedrazzani, R.; Sorlini, S.; Abbà, A.; Bertanza, G. $\mathrm{H}_{2} \mathrm{O}_{2}$ based oxidation processes for the treatment of real high strength aqueous wastes. Sustainability 2017, 9, 244. [CrossRef]

7. Hassaan, M.A.; el Nemr, A.; Madkour, F.F. Testing the advanced oxidation processes on the degradation of Direct Blue 86 dye in wastewater. Egypt. J. Aquat. Res. 2017, 43, 11-19. [CrossRef]

8. Sharma, B.; Dangi, A.K.; Shukla, P. Contemporary enzyme based technologies for bioremediation: A review. J. Environ. Manag. 2018, 210, 10-22. [CrossRef]

9. Khan, S.; Malik, A. Toxicity evaluation of textile effluents and role of native soil bacterium in biodegradation of a textile dye. Environ. Sci. Pollut. Res. 2018, 25, 4446-4458. [CrossRef]

10. Rawat, D.; Mishra, V.; Sharma, R.S. Detoxification of azo dyes in the context of environmental processes. Chemosphere 2016, 155, 591-605. [CrossRef]

11. Garrido-Cardenas, J.A.; Esteban-García, B.; Agüera, A.; Sánchez-Pérez, J.A.; Manzano-Agugliaro, F. Wastewater Treatment by Advanced Oxidation Process and Their Worldwide Research Trends. Int. J. Environ. Res. Public Health 2020, 17, 170. [CrossRef] 
12. Naseem, T.; Durrani, T. The role of some important metal oxide nanoparticles for wastewater and antibacterial applications: A review. Environ. Chem. Ecotoxicol. 2021, 3, 59-75. [CrossRef]

13. Bethi, B.; Sonawane, S.H.; Bhanvase, B.A.; Gumfekar, S.P. Nanomaterials-based advanced oxidation processes for wastewater treatment: A review. Chem. Eng. Process.-Process Intensif. 2016, 109, 178-189. [CrossRef]

14. Nasrollahzadeh, M.; Sajjadi, M.; Iravani, S.; Varma, R.S. Green-synthesized nanocatalysts and nanomaterials for water treatment: Current challenges and future perspectives. J. Hazard. Mater. 2020, 401, 123401. [CrossRef]

15. Ndolomingo, M.J.; Bingwa, N.; Meijboom, R. Review of supported metal nanoparticles: Synthesis methodologies, advantages and application as catalysts. J. Mater. Sci. 2020, 55, 6195-6241. [CrossRef]

16. Divyapriya, G.; Nambi, I.M.; Senthilnathan, J. Nanocatalysts in Fenton based advanced oxidation process for water and wastewater treatment. J. Bionanosci. 2016, 10, 356-368. [CrossRef]

17. Julkapli, N.M.; Bagheri, S.; Hamid, S.B.A. Recent advances in heterogeneous photocatalytic decolorization of synthetic dyes. Sci. World J. 2014, 2014, 1-25. [CrossRef]

18. Simon, J.E.; Decker, E.A.; Ferruzzi, M.; Giusti, M.M.; Mejia, C.D.; Goldschmidt, M.; Talcott, S.T. Establishing standards on colors from natural sources. J. Food Sci. 2017, 82, 2539-2553. [CrossRef]

19. Scotter, M. COLORANTS (COLOURANTS) I Properties and Determinants of Synthetic Pigments. In Encyclopedia of Food Sciences and Nutrition (Second Edition); Caballero, B., Ed.; Academic Press: Oxford, UK, 2003; pp. 1556-1567.

20. Anwer, H.; Mahmood, A.; Lee, J.; Kim, K.-H.; Park, J.-W.; Yip, A.C. Photocatalysts for degradation of dyes in industrial effluents: Opportunities and challenges. Nano Res. 2019, 12, 955-972. [CrossRef]

21. EFSA. Scientific Opinion on the re-evaluation of Brown FK (E 154) as a food additive. EFSA J. 2010, 8. [CrossRef]

22. EFSA Panel on Dietetic Products and Allergies. Scientific Opinion on the appropriateness of the food azo-colours Tartrazine (E 102), Sunset Yellow FCF (E 110), Carmoisine (E 122), Amaranth (E 123), Ponceau 4R (E 124), Allura Red AC (E 129), Brilliant Black BN (E 151), Brown FK (E 154), Brown HT (E 155) and Litholrubine BK (E 180) for inclusion in the list of food ingredients set up in Annex IIIa of Directive 2000/13/EC. EFSA J. 2010, 8, 1778. [CrossRef]

23. EFSA Panel on Food Additives and Nutrient Sources added to Food (ANS). Reconsideration of the temporary ADI and refined exposure assessment for Sunset Yellow FCF (E 110). EFSA J. 2014, 12, 3765. [CrossRef]

24. European Food Safety Authority. Refined exposure assessment for Azorubine/Carmoisine (E 122). EFSA J. 2015, 13, 4072. [CrossRef]

25. EFSA Panel on Food Additives and Nutrient Sources added to Food (ANS). Scientific Opinion on the re-evaluation of Amaranth (E 123) as a food additive. EFSA J. 2010, 8, 1649. [CrossRef]

26. EFSA Panel on Food Additives and Nutrient Sources added to Food (ANS). Scientific Opinion on the re-evaluation of Allura Red AC (E 129) as a food additive. EFSA J. 2009, 7, 1327. [CrossRef]

27. EFSA Panel on Food Additives and Nutrient Sources added to Food (ANS). Scientific Opinion on the re-evaluation of Litholrubine BK (E 180) as a food additive. EFSA J. 2010, 8, 1586. [CrossRef]

28. Kobylewski, S.; Jacobson, M.F. Toxicology of food dyes. Int. J. Occup. Environ. Health 2012, 18, 220-246. [CrossRef]

29. EFSA Panel on Food Additives and Nutrient Sources added to Food (ANS). Scientific Opinion on the re-evaluation of Brilliant Black BN (E 151) as a food additive. EFSA J. 2010, 8, 1540. [CrossRef]

30. EFSA Panel on Food Additives and Nutrient Sources (ANS). Scientific Opinion on the re-evaluation of Brown HT (E 155) as a food additive. EFSA J. 2010, 8, 1536. [CrossRef]

31. Abbas, J.R.; Al-Hamadawi, H.A. Effect of chocolate brown HT E155 on some hormones in male albino rats. Eur. Asian J. BioSci. 2019, 13, 485-489.

32. EFSA Panel on Food Additives and Nutrient Sources added to Food (ANS). Scientific Opinion on the re-evaluation of Patent Blue $\mathrm{V}$ (E 131) as a food additive. EFSA J. 2013, 11, 2818. [CrossRef]

33. EFSA Panel on Food Additives and Nutrient Sources added to Food (ANS). Scientific Opinion on the re-evaluation of Brilliant Blue FCF (E 133) as a food additive. EFSA J. 2010, 8, 1853. [CrossRef]

34. Kumar, N.; Singh, A.; Sharma, D.K.; Kishore, K. Toxicity of food additives. In Food Safety and Human Health; Elsevier: Amsterdam, The Netherlands, 2019; pp. 67-98.

35. EFSA Panel on Food Additives and Nutrient Sources added to Food (ANS). Scientific Opinion on the re-evaluation of Green S (E 142) as a food additive. EFSA J. 2010, 8, 1851. [CrossRef]

36. Villaño, D.; Cristina, G.-V.; Mena, P. Colors: Health Effects. In Encyclopedia of Food and Health; Caballero, B., Finglas, P.M., Toldrá, F., Eds.; Academic Press: Oxford, UK, 2016; Volume 12, p. 31. [CrossRef]

37. EFSA Panel on Food Additives and Nutrient Sources added to Food (ANS). Scientific Opinion on the re-evaluation of Erythrosine (E 127) as a food additive. EFSA J. 2011, 9, 1854. [CrossRef]

38. EFSA Panel on Food Additives and Nutrient Sources added to Food (ANS). Scientific Opinion on the re-evaluation of Quinoline Yellow (E 104) as a food additive. EFSA J. 2009, 7, 1329. [CrossRef]

39. EFSA Panel on Food Additives and Nutrient Sources added to Food (ANS). Scientific Opinion on the re-evaluation of Indigo Carmine (E 132) as a food additive. EFSA J. 2014, 12, 3768. [CrossRef]

40. Sun, W.; Chen, L.; Tian, J.; Wang, J.; He, S. Degradation of a monoazo dye Alizarin Yellow GG in aqueous solutions by gamma irradiation: Decolorization and biodegradability enhancement. Radiat. Phys. Chem. 2013, 83, 86-89. [CrossRef] 
41. Berradi, M.; Hsissou, R.; Khudhair, M.; Assouag, M.; Cherkaoui, O.; El Bachiri, A.; Elharfi, A. Textile finishing dyes and their impact on aquatic environs. Heliyon 2019, 5, e02711. [CrossRef]

42. Wang, J.L.; Xu, L.J. Advanced oxidation processes for wastewater treatment: Formation of hydroxyl radical and application. Crit. Rev. Environ. Sci. Technol. 2012, 42, 251-325. [CrossRef]

43. Vaiano, V.; Iervolino, G.; Rizzo, L.; Sannino, D. Advanced oxidation processes for the removal of food dyes in wastewater. Curr. Org. Chem. 2017, 21, 1068-1073. [CrossRef]

44. Nidheesh, P.V. Graphene-based materials supported advanced oxidation processes for water and wastewater treatment: A review. Environ. Sci. Pollut. Res. 2017, 24, 27047-27069. [CrossRef] [PubMed]

45. Kanakaraju, D.; Glass, B.D.; Oelgemöller, M. Advanced oxidation process-mediated removal of pharmaceuticals from water: A review. J. Environ. Manag. 2018, 219, 189-207. [CrossRef]

46. Ismail, M.; Akhtar, K.; Khan, M.; Kamal, T.; Asiri, A.M.; Seo, J.; Khan, S.B. Pollution, toxicity and carcinogenicity of organic dyes and their catalytic bio-remediation. Curr. Pharm. Des. 2019, 25, 3645-3663. [CrossRef] [PubMed]

47. Deng, Y.; Zhao, R. Advanced oxidation processes (AOPs) in wastewater treatment. Curr. Pollut. Rep. 2015, 1, 167-176. [CrossRef]

48. Cuerda-Correa, E.M.; Alexandre-Franco, M.F.; Fernández-González, C. Advanced oxidation processes for the removal of antibiotics from water. An overview. Water 2020, 12, 102. [CrossRef]

49. Malato, S.; Fernández-Ibáñez, P.; Maldonado, M.I.; Blanco, J.; Gernjak, W. Decontamination and disinfection of water by solar photocatalysis: Recent overview and trends. Catal. Today 2009, 147, 1-59. [CrossRef]

50. Choi, H.; Stathatos, E.; Dionysiou, D.D. Photocatalytic TiO2 films and membranes for the development of efficient wastewater treatment and reuse systems. Desalination 2007, 202, 199-206. [CrossRef]

51. Díaz-Rodríguez, D.; Palacios-Antón, M.E.; Santana, R.M.D.R.; Quiroz-Fernández, L.S.; Gómez-Salcedo, Y.; De Lucena, A.L.A.; Napoleão, D.C.; Rodriguez-Diaz, J.M. Comparative Study of the Degradation of the Diclofenac Drug Using Photo-Peroxidation and Heterogeneous Photocatalysis with UV-C and Solar Radiation. Water Air Soil Pollut. 2020, 231, 1-12. [CrossRef]

52. Giler-Molina, J.M.; Zambrano-Intriago, L.A.; Quiroz-Fernández, L.S.; Napoleão, D.C.; dos Santos Vieira, J.; Simões Oliveira, N.; Rodríguez-Díaz, J.M. Degradation of Oxytetracycline in Aqueous Solutions: Application of Homogeneous and Heterogeneous Advanced Oxidative Processes. Sustainability 2020, 12, 8807. [CrossRef]

53. Zaidan, L.E.M.C.; Sales, R.V.D.L.; Salgado, J.B.D.A.; Da Silva, A.M.R.B.; Napoleão, D.C.; Rodríguez-Díaz, J.M.; Marques, O.M.; Benachour, M.; Da Silva, V.L. Photodegradation applied to the treatment of phenol and derived substances catalyzed by TiO2/BiPO4 and biological toxicity analysis. Environ. Sci. Pollut. Res. 2017, 24, 6002-6012. [CrossRef]

54. Nascimento, G.E.D.; Cavalcanti, V.O.M.; Santana, R.M.R.; Sales, D.C.S.; Rodríguez-Díaz, J.M.; Napoleão, D.; Duarte, M. Degradation of a Sunset Yellow and Tartrazine Dye Mixture: Optimization Using Statistical Design and Empirical Mathematical Modeling. Water Air Soil Pollut. 2020, 231, 1-17. [CrossRef]

55. Nascimento, G.E.D.; Oliveira, M.A.S.; Santana, R.M.D.R.; Ribeiro, B.G.; Sales, D.C.S.; Rodríguez-Díaz, J.M.; Napoleão, D.; Sobrinho, M.A.D.M.; Duarte, M.M.M.B. Investigation of paracetamol degradation using LED and UV-C photo-reactors. Water Sci. Technol. 2020, 81, 2545-2558. [CrossRef] [PubMed]

56. Wang, F.; van Halem, D.; Liu, G.; Lekkerkerker-Teunissen, K.; van der Hoek, J.P. Effect of residual H2O2 from advanced oxidation processes on subsequent biological water treatment: A laboratory batch study. Chemosphere 2017, 185, 637-646. [CrossRef]

57. Muruganandham, M.; Suri, R.P.S.; Jafari, S.; Sillanpää, M.; Lee, G.-J.; Wu, J.; Swaminathan, M. Recent developments in homogeneous advanced oxidation processes for water and wastewater treatment. Int. J. Photoenergy 2014, 2014. [CrossRef]

58. Xiao, S.; Cheng, M.; Zhong, H.; Liu, Z.; Liu, Y.; Yang, X.; Liang, Q. Iron-mediated activation of persulfate and peroxymonosulfate in both homogeneous and heterogeneous ways: A review. Chem. Eng. J. 2020, 384, 123265. [CrossRef]

59. Kavitha, V.; Palanivelu, K. The role of ferrous ion in Fenton and photo-Fenton processes for the degradation of phenol. Chemosphere 2004, 55, 1235-1243. [CrossRef]

60. Kumar, A.; Paliwal, M.; Ameta, R.; Ameta, S. Oxidation of fast green FCF by the solar photo-Fenton process. J. Iran. Chem. Soc. 2008, 5, 346-351. [CrossRef]

61. Benincá, C.; Peralta-Zamora, P.; Camargo, R.C.; Tavares, C.R.G.; Zanoelo, E.F.; Igarashi-Mafra, L. Kinetics of oxidation of ponceau 4R in aqueous solutions by Fenton and photo-Fenton processes. React. Kinet. Mech. Catal. 2012, 105, 293-306. [CrossRef]

62. Oancea, P.; Meltzer, V. Photo-Fenton process for the degradation of Tartrazine (E102) in aqueous medium. J. Taiwan Inst. Chem. Eng. 2013, 44, 990-994. [CrossRef]

63. Benincá, C.; Peralta-Zamora, P.; Tavares, C.R.G.; Igarashi-Mafra, L. Degradation of an azo dye (Ponceau 4R) and treatment of wastewater from a food industry by ozonation. Ozone Sci. Eng. 2013, 35, 295-301. [CrossRef]

64. Ruhul, A.; Kalam, M.; Masjuki, H.; Fattah, I.R.; Reham, S.; Rashed, M. State of the art of biodiesel production processes: A review of the heterogeneous catalyst. RSC Adv. 2015, 5, 101023-101044. [CrossRef]

65. Fox, M.A.; Dulay, M.T. Heterogeneous photocatalysis. Chem. Rev. 1993, 93, 341-357. [CrossRef]

66. Kudo, A.; Miseki, Y. Heterogeneous photocatalyst materials for water splitting. Chem. Soc. Rev. 2009, 38, 253-278. [CrossRef] [PubMed]

67. Rosu, M.-C.; Coros, M.; Pogacean, F.; Magerusan, L.; Socaci, C.; Turza, A.; Pruneanu, S.M. Azo dyes degradation using TiO ${ }_{2}-$ $\mathrm{Pt}$ /graphene oxide and $\mathrm{TiO}_{2}-\mathrm{Pt} /$ reduced graphene oxide photocatalysts under UV and natural sunlight irradiation. Solid State Sci. 2017, 70, 13-20. [CrossRef] 
68. Pascariu, P.; Cojocaru, C.; Samoila, P.; Airinei, A.; Olaru, N.; Rusu, D.; Rosca, I.; Suchea, M. Photocatalytic and antimicrobial activity of electrospun ZnO: Ag nanostructures. J. Alloys Compd. 2020, 834, 155144. [CrossRef]

69. Roşu, M.-C.; Socaci, C.; Floare-Avram, V.; Borodi, G.; Pogăcean, F.; Coros, M.; Măgeruşan, L.; Pruneanu, S.M. Photocatalytic performance of graphene/TiO2-Ag composites on amaranth dye degradation. Mater. Chem. Phys. 2016, 179, 232-241. [CrossRef]

70. Mahdiani, M.; Soofivand, F.; Ansari, F.; Salavati-Niasari, M. Grafting of $\mathrm{CuFe}_{12} \mathrm{O}_{19}$ nanoparticles on $\mathrm{CNT}$ and graphene: Eco-friendly synthesis, characterization and photocatalytic activity. J. Clean. Prod. 2018, 176, 1185-1197. [CrossRef]

71. Medina-Ramírez, I.; Hernández-Ramírez, A.; Maya-Trevino, M.L. Synthesis Methods for Photocatalytic Materials. In Photocatalytic Semiconductors; Springer: Berlin/Heidelberg, Germany, 2015; pp. 69-102.

72. Azimi, S. Sol-gel synthesis and structural characterization of nano-thiamine hydrochloride structure. Int. Sch. Res. Not. 2013, 2013, 815071. [CrossRef]

73. Khiabani, P.S.; Soeriyadi, A.; Nam, E.V.; Peterson, J.R.; Webb, J.E.; Thordarson, P.; Donald, W.; Gooding, J.J. Understanding the performance of a paper-based UV exposure sensor: The photodegradation mechanism of brilliant blue FCF in the presence of $\mathrm{TiO}_{2}$ photocatalysts in both the solid state and solution. Rapid Commun. Mass Spectrom. 2019, 33, 1076-1083. [CrossRef]

74. Rajamanickam, D.; Dhatshanamurthi, P.; Shanthi, M. Preparation and characterization of $\mathrm{SeO}_{2} / \mathrm{TiO}_{2}$ composite photocatalyst with excellent performance for sunset yellow azo dye degradation under natural sunlight illumination. Spectrochim. Acta Part A Mol. Biomol. Spectrosc. 2015, 138, 489-498. [CrossRef]

75. Costa, L.L.; Prado, A.G. $\mathrm{TiO}_{2}$ nanotubes as recyclable catalyst for efficient photocatalytic degradation of indigo carmine dye. J. Photochem. Photobiol. A Chem. 2009, 201, 45-49. [CrossRef]

76. Rajeshwar, K.; Osugi, M.; Chanmanee, W.; Chenthamarakshan, C.; Zanoni, M.V.B.; Kajitvichyanukul, P.; Krishnan-Ayer, R. Heterogeneous photocatalytic treatment of organic dyes in air and aqueous media. J. Photochem. Photobiol. C Photochem. Rev. 2008, 9, 171-192. [CrossRef]

77. Sudrajat, H.; Babel, S.; Sakai, H.; Takizawa, S. Rapid enhanced photocatalytic degradation of dyes using novel N-doped $\mathrm{ZrO}_{2}$. J. Environ. Manag. 2016, 165, 224-234. [CrossRef] [PubMed]

78. Shaheen, K.; Suo, H.; Arshad, T.; Shah, Z.; Khan, S.A.; Khan, S.B.; Khan, M.N.; Liu, M.; Ma, L.; Cui, J.; et al. Metal oxides nanomaterials for the photocatalytic mineralization of toxic water wastes under solar light illumination. J. Water Process Eng. 2020, 34, 101138. [CrossRef]

79. Fujishima, A.; Zhang, X.; Tryk, D.A. $\mathrm{TiO}_{2}$ photocatalysis and related surface phenomena. Surf. Sci. Rep. 2008, 63, 515-582. [CrossRef]

80. Liu, G.; Wang, L.; Yang, H.G.; Cheng, H.-M.; Lu, G.Q.M. Titania-based photocatalysts-Crystal growth, doping and heterostructuring. J. Mater. Chem. 2010, 20, 831-843. [CrossRef]

81. Akpan, U.G.; Hameed, B.H. Parameters affecting the photocatalytic degradation of dyes using $\mathrm{TiO}_{2}$-based photocatalysts: A review. J. Hazard. Mater. 2009, 170, 520-529. [CrossRef] [PubMed]

82. Twigg, M.V. Catalyst Handbook; Routledge: Abingdon, UK, 2018.

83. Zhao, Q.; Mao, Q.; Zhou, Y.; Wei, J.; Liu, X.; Yang, J.; Luo, L.; Zhang, J.; Chen, H.; Tang, L. Metal-free carbon materialscatalyzed sulfate radical-based advanced oxidation processes: A review on heterogeneous catalysts and applications. Chemosphere 2017, 189, 224-238. [CrossRef] [PubMed]

84. Chen, Y.; Li, N.; Zhang, Y.; Zhang, L. Novel low-cost Fenton-like layered Fe-titanate catalyst: Preparation, characterization and application for degradation of organic colorants. J. Colloid Interface Sci. 2014, 422, 9-15. [CrossRef] [PubMed]

85. Kiss, F.E.; Jovanović, M.; Bošković, G.C. Economic and ecological aspects of biodiesel production over homogeneous and heterogeneous catalysts. Fuel Process. Technol. 2010, 91, 1316-1320. [CrossRef]

86. Teh, C.M.; Mohamed, A.R. Roles of titanium dioxide and ion-doped titanium dioxide on photocatalytic degradation of organic pollutants (phenolic compounds and dyes) in aqueous solutions: A review. J. Alloys Compd. 2011, 509, 1648-1660. [CrossRef]

87. Tekin, G.; Ersöz, G.; Atalay, S. Visible light assisted Fenton oxidation of tartrazine using metal doped bismuth oxyhalides as novel photocatalysts. J. Environ. Manag. 2018, 228, 441-450. [CrossRef]

88. Wang, D.; Astruc, D. Fast-growing field of magnetically recyclable nanocatalysts. Chem. Rev. 2014, 114, 6949-6985. [CrossRef] [PubMed]

89. Anjum, M.; Miandad, R.; Waqas, M.; Gehany, F.; Barakat, M. Remediation of wastewater using various nano-materials. Arab. J. Chem. 2019, 12, 4897-4919. [CrossRef]

90. Gahlawat, G.; Choudhury, A.R. A review on the biosynthesis of metal and metal salt nanoparticles by microbes. RSC Adv. 2019, 9, 12944-12967. [CrossRef]

91. Aoudjit, L.; Martins, P.; Madjene, F.; Petrovykh, D.; Lanceros-Mendez, S. Photocatalytic reusable membranes for the effective degradation of tartrazine with a solar photoreactor. J. Hazard. Mater. 2018, 344, 408-416. [CrossRef]

92. Homaeigohar, S. The nanosized dye adsorbents for water treatment. Nanomaterials 2020, 10, 295. [CrossRef]

93. Thakur, M.; Sharma, G.; Ahamad, T.; Ghfar, A.A.; Pathania, D.; Naushad, M. Efficient photocatalytic degradation of toxic dyes from aqueous environment using gelatin-Zr (IV) phosphate nanocomposite and its antimicrobial activity. Colloids Surf. B Biointerfaces 2017, 157, 456-463. [CrossRef] [PubMed]

94. Karkmaz, M.; Puzenat, E.; Guillard, C.; Herrmann, J. Photocatalytic degradation of the alimentary azo dye amaranth: Mineralization of the azo group to nitrogen. Appl. Catal. B Environ. 2004, 51, 183-194. [CrossRef] 
95. Orooji, Y.; Mohassel, R.; Amiri, O.; Sobhani, A.; Salavati-Niasari, M. Gd $2 Z_{n M n O} / Z_{n O}$ nanocomposites: Green sol-gel autocombustion synthesis, characterization and photocatalytic degradation of different dye pollutants in water. J. Alloys Compd. 2020, 835, 155240. [CrossRef]

96. Taylor, M.G.; Austin, N.; Gounaris, C.E.; Mpourmpakis, G. Catalyst design based on morphology-and environment-dependent adsorption on metal nanoparticles. ACS Catal. 2015, 5, 6296-6301. [CrossRef]

97. Li, Y.; Shen, W. Morphology-dependent nanocatalysts: Rod-shaped oxides. Chem. Soc. Rev. 2014, 43, 1543-1574. [CrossRef] [PubMed]

98. Verma, P.; Mori, K.; Kuwahara, Y.; Raja, R.; Yamashita, H. Plasmonic nanocatalysts for visible-NIR light induced hydrogen generation from storage materials. Mater. Adv. 2021, 2, 880-906. [CrossRef]

99. Bahadori, E.; Vaiano, V.; Esposito, S.; Armandi, M.; Sannino, D.; Bonelli, B. Photo-activated degradation of tartrazine by H2O2 as catalyzed by both bare and Fe-doped methyl-imogolite nanotubes. Catal. Today 2018, 304, 199-207. [CrossRef]

100. Darwish, M.; Mohammadi, A.; Assi, N. Microwave-assisted polyol synthesis and characterization of pvp-capped cds nanoparticles for the photocatalytic degradation of tartrazine. Mater. Res. Bull. 2016, 74, 387-396. [CrossRef]

101. Nazim, M.; Khan, A.A.P.; Asiri, A.M.; Kim, J.H. Exploring Rapid Photocatalytic Degradation of Organic Pollutants with Porous CuO Nanosheets: Synthesis, Dye Removal, and Kinetic Studies at Room Temperature. ACS Omega 2021, 6, 2601-2612. [CrossRef]

102. Zhang, T.; Souza, I.P.; Xu, J.; Almeida, V.C.; Asefa, T. Mesoporous graphitic carbon nitrides decorated with cu nanoparticles: Efficient photocatalysts for degradation of tartrazine yellow dye. Nanomaterials 2018, 8, 636. [CrossRef]

103. Alcantara-Cobos, A.; Gutiérrez-Segura, E.; Solache-Ríos, M.; Amaya-Chávez, A.; Solís-Casados, D. Tartrazine removal by ZnO nanoparticles and a zeolite- $\mathrm{ZnO}$ nanoparticles composite and the phytotoxicity of $\mathrm{ZnO}$ nanoparticles. Microporous Mesoporous Mater. 2020, 302, 110212. [CrossRef]

104. Rao, M.P.; Wu, J.J.; Asiri, A.M.; Anandan, S. Photocatalytic degradation of tartrazine dye using CuO straw-sheaf-like nanostructures. Water Sci. Technol. 2017, 75, 1421-1430. [CrossRef]

105. Türkyılmaz, Ş.Ş.; Güy, N.; Özacar, M. Photocatalytic efficiencies of Ni, Mn, Fe and Ag doped ZnO nanostructures synthesized by hydrothermal method: The synergistic/antagonistic effect between $\mathrm{ZnO}$ and metals. J. Photochem. Photobiol. A Chem. 2017, 341, 39-50. [CrossRef]

106. Balu, S.; Velmurugan, S.; Palanisamy, S.; Chen, S.-W.; Velusamy, V.; Yang, T.C.; El-Shafey, E.-S.I. Synthesis of $\alpha$-Fe ${ }_{2} \mathrm{O}_{3}$ decorated g- $\mathrm{C}_{3} \mathrm{~N}_{4} / \mathrm{ZnO}$ ternary Z-scheme photocatalyst for degradation of tartrazine dye in aqueous media. J. Taiwan Inst. Chem. Eng. 2019, 99, 258-267. [CrossRef]

107. Zhou, Y.; Qin, Y.; Dai, W.; Luo, X. Highly Efficient Degradation of Tartrazine with a Benzoic Acid/TiO 2 System. ACS Omega 2019, 4, 546-554. [CrossRef] [PubMed]

108. Cubas, P.d.; Semkiw, A.W.; Monteiro, F.C.; Weinert, P.L.; Monteiro, J.F.H.L.; Fujiwara, S.T. Synthesis of $\mathrm{CuCr}_{2} \mathrm{O}_{4}$ by selfcombustion method and photocatalytic activity in the degradation of Azo Dye with visible light. J. Photochem. Photobiol. A Chem. 2020, 401, 112797. [CrossRef]

109. David, L.; Moldovan, B. Green synthesis of biogenic silver nanoparticles for efficient catalytic removal of harmful organic dyes. Nanomaterials 2020, 10, 202. [CrossRef]

110. Pavanello, A.; Blasco, A.; Johnston, P.F.; Miranda, M.A.; Marin, M.L. Enhanced photodegradation of synthetic dyes mediated by Ag3PO4-based semiconductors under visible light irradiation. Catalysts 2020, 10, 774. [CrossRef]

111. Marković, M.; Marinović, S.; Mudrinić, T.; Ajduković, M.; Jović-Jovičić, N.; Mojović, Z.; Orlić, J.; Milutinović-Nikolić, A.; Bankovic, P. Co (II) impregnated Al (III)-pillared montmorillonite-Synthesis, characterization and catalytic properties in Oxone ${ }^{\circledR}$ activation for dye degradation. Appl. Clay Sci. 2019, 182, 105276. [CrossRef]

112. Vu, A.-T.; Xuan, T.N.; Lee, C.-H. Preparation of mesoporous $\mathrm{Fe}_{2} \mathrm{O}_{3} \bullet \mathrm{SiO}_{2}$ composite from rice husk as an efficient heterogeneous Fenton-like catalyst for degradation of organic dyes. J. Water Process Eng. 2019, 28, 169-180. [CrossRef]

113. Ajduković, M.; Stojadinović, S.; Marinović, S.; Milutinović-Nikolić, A.; Dojčinović, B.; Banković, P. Activation of Oxone ${ }^{\circledR}$ with plasma deposited mixed cobalt and alumina oxide for the dye degradation. Appl. Surf. Sci. 2020, 503, 144144. [CrossRef]

114. Souza, I.P.; Crespo, L.H.; Spessato, L.; Melo, S.A.; Martins, A.F.; Cazetta, A.L.; Almeida, V.C. Optimization of thermal conditions of sol-gel method for synthesis of $\mathrm{TiO}_{2}$ using RSM and its influence on photodegradation of tartrazine yellow dye. J. Environ. Chem. Eng. 2021, 9, 104753. [CrossRef]

115. Guo, R.; Wang, Y.; Li, J.; Cheng, X.; Dionysiou, D.D. Sulfamethoxazole degradation by visible light assisted peroxymonosulfate process based on nanohybrid manganese dioxide incorporating ferric oxide. Appl. Catal. B Environ. 2020, 278, 119297. [CrossRef]

116. Khorasanizadeh, M.H.; Ghiyasiyan-Arani, M.; Monsef, R.; Salavati-Niasari, M.; Moayedi, H. Ultrasound-accelerated synthesis of uniform DyVO4 nanoparticles as high activity visible-light-driven photocatalyst. Ultrason. Sonochem. 2019, 59, 104719. [CrossRef]

117. Zinatloo-Ajabshir, S.; Morassaei, M.S.; Salavati-Niasari, M. Eco-friendly synthesis of $\mathrm{Nd}_{2} \mathrm{Sn}_{2} \mathrm{O}_{7}$-based nanostructure materials using grape juice as green fuel as photocatalyst for the degradation of erythrosine. Compos. Part B Eng. 2019, 167, 643-653. [CrossRef]

118. Mazloom, F.; Ghiyasiyan-Arani, M.; Monsef, R.; Salavati-Niasari, M. Photocatalytic degradation of diverse organic dyes by sol-gel synthesized $\mathrm{Cd}_{2} \mathrm{~V}_{2} \mathrm{O}_{7}$ nanostructures. J. Mater. Sci. Mater. Electron. 2018, 29, 18120-18127. [CrossRef]

119. Sakir, M.; Salem, S.; TapanSanduvacae, S.; Sahmetliogluaf, E.; Sarp, G.; SerdarOnsesac, M.; Yilmazabd, E. Photocatalytic green fabrication of $\mathrm{Au}$ nanoparticles on $\mathrm{ZnO}$ nanorods modified membrane as flexible and photocatalytic active reusable SERS substrates. Colloids Surf. A Physicochem. Eng. Asp. 2020, 585, 124088. [CrossRef] 
120. Soofivand, F.; Esmaeili, E.; Sabet, M.; Salavati-Niasari, M. Simple synthesis, characterization and investigation of photocatalytic activity of NiS 2 nanoparticles using new precursors by hydrothermal method. J. Mater. Sci. Mater. Electron. 2018, $29,858-865$. [CrossRef]

121. Zinatloo-Ajabshir, S.; Salehi, Z.; Salavati-Niasari, M. Green synthesis of $\mathrm{Dy}_{2} \mathrm{Ce}_{2} \mathrm{O}_{7}$ ceramic nanostructures using juice of Punica granatum and their efficient application as photocatalytic degradation of organic contaminants under visible light. Ceram. Int. 2018, 44, 3873-3883. [CrossRef]

122. Shirzadi-Ahodashti, M.; Ebrahimzadeh, M.A.; Amiri, O.; Naghizadeh, A.; Mortazavi-Derazkola, S. Novel NiFe/Si/Au magnetic nanocatalyst: Biogenic synthesis, efficient and reusable catalyst with enhanced visible light photocatalytic degradation and antibacterial activity. Appl. Organomet. Chem. 2020, 34, e5467. [CrossRef]

123. Hunge, Y.; Yadav, A.; Mathe, V. Ultrasound assisted synthesis of WO3-ZnO nanocomposites for brilliant blue dye degradation. Ultrason. Sonochem. 2018, 45, 116-122. [CrossRef]

124. Nikravesh, B.; Shomalnasab, A.; Nayyer, A.; Aghababaei, N.; Zarebi, R.; Ghanbari, F. UV/Chlorine process for dye degradation in aqueous solution: Mechanism, affecting factors and toxicity evaluation for textile wastewater. J. Environ. Chem. Eng. 2020, 8, 104244. [CrossRef]

125. Naik, A.P.; Mittal, H.; Wadi, V.K.S.; Sane, L.; Raj, A.; Alhassan, S.; Al Alili, A.; Bhosale, S.V.; Morajkar, P.P. Super porous TiO 2 photocatalyst: Tailoring the agglomerate porosity into robust structural mesoporosity with enhanced surface area for efficient remediation of azo dye polluted waste water. J. Environ. Manag. 2020, 258, 110029. [CrossRef]

126. Lamba, R.; Umar, A.; Mehta, S.; Kansal, S.K. Enhanced visible light driven photocatalytic application of Ag2O decorated ZnO nanorods heterostructures. Sep. Purif. Technol. 2017, 183, 341-349. [CrossRef]

127. Zhang, M.-W.; Lin, K.-Y.A.; Huang, C.-F.; Tong, S. Enhanced degradation of toxic azo dye, amaranth, in water using Oxone catalyzed by MIL-101-NH2 under visible light irradiation. Sep. Purif. Technol. 2019, 227, 115632. [CrossRef]

128. Zhang, M.-W.; Yang, M.-T.; Tong, S.; Lin, K.-Y.A. Ferrocene-modified iron-based metal-organic frameworks as an enhanced catalyst for activating oxone to degrade pollutants in water. Chemosphere 2018, 213, 295-304. [CrossRef] [PubMed]

129. Li, M.-H.; Lin, K.-Y.A.; Yang, M.-T.; Thanh, B.X.; Tsang, D.C. Prussian Blue Analogue-derived co/fe bimetallic nanoparticles immobilized on $\mathrm{S} / \mathrm{N}$-doped carbon sheet as a magnetic heterogeneous catalyst for activating peroxymonosulfate in water. Chemosphere 2020, 244, 125444. [CrossRef] [PubMed]

130. Balu, S.; Chen, Y.-L.; Yang, T.C.-K.; Chen, J.-N.; Chen, S.-W. Effect of ultrasound-induced hydroxylation and exfoliation on $\mathrm{P} 90-\mathrm{TiO}_{2} / \mathrm{g}-\mathrm{C}_{3} \mathrm{~N}_{4}$ hybrids with enhanced optoelectronic properties for visible-light photocatalysis and electrochemical sensing. Ceram. Int. 2020, 46, 18002-18018. [CrossRef]

131. Feizi, R.; Ahmad, M.; Jorfi, S.; Ghanbari, F. Sunset yellow degradation by ultrasound/peroxymonosulfate $/ \mathrm{CuFe}_{2} \mathrm{O}_{4}$ : Influential factors and degradation processes. Korean J. Chem. Eng. 2019, 36, 886-893. [CrossRef]

132. Deepika, S.; Harishkumar, R.; Dinesh, M.; Abarna, R.; Anbalagan, M.; Roopan, S.M.; Selvaraj, C.I. Photocatalytic degradation of synthetic food dye, sunset yellow FCF (FD\&C yellow no. 6) by Ailanthus excelsa Roxb. possessing antioxidant and cytotoxic activity. J. Photochem. Photobiol. B Biol. 2017, 177, 44-55. [CrossRef]

133. Hassanien, R.; Abed-Elmageed, A.A.; Husein, D.Z. Eco-Friendly Approach to Synthesize Selenium Nanoparticles: Photocatalytic Degradation of Sunset Yellow Azo Dye and Anticancer Activity. ChemistrySelect 2019, 4, 9018-9026. [CrossRef]

134. Pinheiro, A.C.; Bernardino, T.S.; Junior, F.E.; Lanza, M.R.; Barros, W.R. Enhanced electrodegradation of the Sunset Yellow dye in acid media by heterogeneous Photoelectro-Fenton process using $\mathrm{Fe}_{3} \mathrm{O}_{4}$ nanoparticles as a catalyst. J. Environ. Chem. Eng. 2020, 8, 103621. [CrossRef]

135. Xia, L.; Jiang, X.; Cheng, Z.; Liao, Y.; Wang, Z.; Pu, Q.; Duan, M. Synthesis of Pp-16@ Ag/AgCl of high performance photocatalyst particles for decomposition of Rhodamine B and fast green dyes. Mater. Chem. Phys. 2018, 218, 98-107. [CrossRef]

136. Sharma, G.; Kumar, A.; Sharma, S.; Al-Saeedi, S.I.; Al-Senani, G.M.; Nafady, A.; Ahamad, T.; Naushad, M.; Stadler, F.J. Fabrication of oxidized graphite supported $\mathrm{La} 2 \mathrm{O} 3 / \mathrm{ZrO} 2$ nanocomposite for the photoremediation of toxic fast green dye. J. Mol. Liq. 2019, 277, 738-748. [CrossRef]

137. Muhambihai, P.; Rama, V.; Subramaniam, P. Photocatalytic degradation of aniline blue, brilliant green and direct red 80 using $\mathrm{NiO} / \mathrm{CuO}, \mathrm{CuO} / \mathrm{ZnO}$ and $\mathrm{ZnO} / \mathrm{NiO}$ nanocomposites. Environ. Nanotechnol. Monit. Manag. 2020, 14, 100360. [CrossRef]

138. Sharma, G.; Bhogal, S.; Gupta, V.K.; Agarwal, S.; Kumar, A.; Pathania, D.; Mola, G.T.; Stadler, F.J. Algal biochar reinforced trimetallic nanocomposite as adsorptional/photocatalyst for remediation of malachite green from aqueous medium. J. Mol. Liq. 2019, 275, 499-509. [CrossRef]

139. Rane, Y.; Shende, D.; Raghuwanshi, M.; Koli, R.; Gosavi, S.; Deshpande, N. Visible-light assisted CdO nanowires photocatalyst for toxic dye degradation studies. Optik 2019, 179, 535-544. [CrossRef]

140. Agorku, E.S.; Mamo, M.A.; Mamba, B.B.; Pandey, A.C.; Mishra, A.K. Palladium-decorated zinc sulfide/reduced graphene oxide nanocomposites for enhanced visible light-driven photodegradation of indigo carmine. Mater. Sci. Semicond. Process. 2015, 33, 119-126. [CrossRef]

141. Rekhila, G.; Saidani, A.; Hocine, F.; Hariz, S.H.B.; Trari, M. Characterization of the hetero-system $\mathrm{ZnCo}_{2} \mathrm{O}_{4} / \mathrm{ZnO}_{\mathrm{prepared}}$ by sol gel: Application to the degradation of Ponceau 4R under solar light. Appl. Phys. A 2020, 126, 1-8. [CrossRef]

142. Mossmann, A.; Dotto, G.L.; Hotza, D.; Jahn, S.L.; Foletto, E.L. Preparation of polyethylene-supported zero-valent iron buoyant catalyst and its performance for Ponceau 4R decolorization by photo-Fenton process. J. Environ. Chem. Eng. 2019, 7, 102963. [CrossRef] 
143. Barrera, H.; Cruz-Olivares, J.; Frontana-Uribe, B.A.; Gómez-Díaz, A.; Reyes-Romero, P.G.; Barrera-Diaz, C.E. Electro-OxidationPlasma Treatment for Azo Dye Carmoisine (Acid Red 14) in an Aqueous Solution. Materials 2020, 13, 1463. [CrossRef]

144. Yaqoob, A.A.; Parveen, T.; Umar, K.; Ibrahim, M.N.M. Role of nanomaterials in the treatment of wastewater: A review. Water 2020, 12, 495. [CrossRef]

145. Gautam, R.K.; Chattopadhyaya, M.C. Chapter 6-Sorption of Dyes on Graphene-Based Nanocomposites. In Nanomaterials for Wastewater Remediation; Gautam, R.K., Chattopadhyaya, M.C., Eds.; Butterworth-Heinemann: Boston, MA, USA, 2016; pp. 111-138.

146. Wang, C.; Astruc, D. Recent developments of metallic nanoparticle-graphene nanocatalysts. Prog. Mater. Sci. 2018, 94, 306-383. [CrossRef]

147. Gan, Z.; Wu, X.; Meng, M.; Zhu, X.; Yang, L.; Chu, P.K. Photothermal contribution to enhanced photocatalytic performance of graphene-based nanocomposites. ACS Nano 2014, 8, 9304-9310. [CrossRef]

148. Singh, P.; Shandilya, P.; Raizada, P.; Sudhaik, A.; Rahmani-Sani, A.; Hosseini-Bandegharaei, A. Review on various strategies for enhancing photocatalytic activity of graphene based nanocomposites for water purification. Arab. J. Chem. 2020, 13, 3498-3520. [CrossRef]

149. Viciano-Chumillas, M.; Mon, M.; Ferrando-Soria, J.; Corma, A.; Leyva-Pérez, A.; Armentano, D.; Pardo, E. Metal-organic frameworks as chemical nanoreactors: Synthesis and stabilization of catalytically active metal species in confined spaces. Acc. Chem. Res. 2020, 53, 520-531. [CrossRef] [PubMed]

150. Chen, L.; Zhang, X.; Zhou, J.; Xie, Z.; Kuang, Q.; Zheng, L. A nano-reactor based on PtNi@ metal-organic framework composites loaded with polyoxometalates for hydrogenation-esterification tandem reactions. Nanoscale 2019, 11, 3292-3299. [CrossRef] [PubMed]

151. Thomas, N.; Dionysiou, D.D.; Pillai, S.C. Heterogeneous Fenton catalysts: A review of recent advances. J. Hazardous Mater. 2020, 404, 124082. [CrossRef]

152. Gautam, P.K.; Singh, A.; Misra, K.; Sahoo, A.K.; Samanta, S.K. Synthesis and applications of biogenic nanomaterials in drinking and wastewater treatment. J. Environ. Manag. 2019, 231, 734-748. [CrossRef]

153. Jo, W.-K.; Kumar, S.; Isaacs, M.A.; Lee, A.F.; Karthikeyan, S. Cobalt promoted $\mathrm{TiO}_{2} / \mathrm{GO}$ for the photocatalytic degradation of oxytetracycline and Congo Red. Appl. Catal. B Environ. 2017, 201, 159-168. [CrossRef]

154. Jiang, D.; Xu, P.; Wang, H.; Zeng, G.; Huang, D.; Chen, M.; Lai, C.; Zhang, C.; Wan, J.; Xue, W. Strategies to improve metal organic frameworks photocatalyst's performance for degradation of organic pollutants. Coord. Chem. Rev. 2018, 376, 449-466. [CrossRef]

155. Zhang, C.; Guo, D.; Shen, T.; Hou, X.; Zhu, M.; Liu, S.; Hu, Q. Titanium dioxide/magnetic metal-organic framework preparation for organic pollutants removal from water under visible light. Colloids Surf. A Physicochem. Eng. Asp. 2020, 589, 124484. [CrossRef]

156. Liu, C.; Zhang, W.; Wang, N.; Guo, P.; Muhler, M.; Wang, Y.; Lin, S.; Chen, Z.; Yang, G. Highly efficient photocatalytic degradation of dyes by a copper-triazolate metal-organic framework. Chem.-A Eur. J. 2018, 24, 16804-16813. [CrossRef] [PubMed]

157. Ali, I.; Peng, C.; Khan, Z.M.; Naz, I.; Sultan, M.; Ali, M.; Abbasi, I.A.; Islam, T.; Ye, T. Overview of microbes based fabricated biogenic nanoparticles for water and wastewater treatment. J. Environ. Manag. 2019, 230, 128-150. [CrossRef] [PubMed]

158. Marimuthu, S.; Antonisamy, A.J.; Malayandi, S.; Rajendran, K.; Tsai, P.-C.; Pugazhendhi, A.; Ponnusamy, V.K. Silver nanoparticles in dye effluent treatment: A review on synthesis, treatment methods, mechanisms, photocatalytic degradation, toxic effects and mitigation of toxicity. J. Photochem. Photobiol. B Biol. 2020, 205, 111823. [CrossRef] [PubMed]

159. Trimm, D. The regeneration or disposal of deactivated heterogeneous catalysts. Appl. Catal. A Gen. 2001, 212, 153-160. [CrossRef]

160. Lu, S.; Liu, L.; Demissie, H.; An, G.; Wang, D. Design and application of metal-organic frameworks and derivatives as heterogeneous Fenton-like catalysts for organic wastewater treatment: A review. Environ. Int. 2021, 146, 106273. [CrossRef] [PubMed] 